\begin{tabular}{|c|l|}
\hline Title & Crustal structure across the More margin, mid-Norway, from wide angle seismic and gravity data \\
\hline Author(s) & $\begin{array}{l}\text { Kvarven, Trond; Ebbing, Jorg; Mjelde, Rolf; Faleide, Jan Inge; Libak, A udun; Thy bo, Hans; Flueh, Ernst R.; Murai, } \\
\text { Yoshio }\end{array}$ \\
\hline Citation & $\begin{array}{l}\text { Tectonophysics, 626, 21-40 } \\
\text { https:/doi.org/_0.1016/tecto.2014.03.021 }\end{array}$ \\
\hline Issue Date & 201406-20 \\
\hline Doc URL & http://hdl.handle.net/2115/56858 \\
\hline Rights & (C) 2014 Elsevier B.V. A Al rights reserved. \\
\hline Type & article (author version) \\
\hline File Information & Tectonophysics_626_21-.pdf \\
\hline
\end{tabular}

Instructions for use 


\section{Crustal structure across the Møre margin, mid-Norway, from wide-angle seismic and gravity data.}

Trond Kvarven $^{1}$, Jörg Ebbing ${ }^{2,7,8}$, Rolf Mjelde ${ }^{1}$, Jan Inge Faleide ${ }^{3}$, Audun Libak ${ }^{1}$, Hans Thybo $^{4}$, Ernst R. Flueh ${ }^{5}$ and Yoshio Murai ${ }^{6}$.

In preparation: Tectonophysics.

${ }^{1}$ Department of Earth Science, University of Bergen, Allegaten 41, N-5007 Bergen, Norway. E-mail: trond.kvarven@geo.uib.no

${ }^{2}$ Geological Survey of Norway, N-7491 Trondheim, Norway

${ }^{3}$ Department of Geosciences, University of Oslo, P.O. Box 1047 Blindern, N-0316 Oslo, Norway

${ }^{4}$ Department of Geography and Geology, University of Copenhagen, Copenhagen, Denmark

${ }^{5}$ IFM-GEOMAR, Wischhofstr. 1-3, D-24148 Kiel, Germany

${ }^{6}$ Institute of Seismology and Volcanology, Hokkaido University, Sapporo, Japan.

7 Department of Petroleum Engineering and Applied Geophysics, NTNU Trondheim, Norway

8 Now at: Department of Geosciences, Christian-Albrechts-University Kiel, Germany

\section{Abstract}

The Møre Margin in the NE Atlantic represents a dominantly passive margin with an unusual abrupt transition from high alpine topography onshore to a deep sedimentary basin offshore. In order to study this transition in detail, three ocean bottom seismometer profiles with deep seismic reflection and refraction data were acquired in 2009; two dip-profiles which were extended by land stations, and one tie-profile parallel to the strike of the Møre-Trøndelag Fault Complex. The modelling of the wide-angle seismic data was performed with a combined inversion and forward modelling approach and validated with a 3D-density model. Modeling of the geophysical data indicates the presence of a 12-15 km thick accumulation of sedimentary rocks in the Møre Basin. The modeling of the strike profile located closer to land shows a decrease in crustal velocity from north to south. Near the coast we observe an intracrustal reflector under the Trøndelag Platform, but not under the Slørebotn Sub-basin. Furthermore, two lower crustal high-velocity bodies are modeled, one located near the Møre Marginal High and one beneath the Slørebotn Sub-basin. While the outer lower crustal body is modeled with a density allowing an interpretation as magmatic underplating, the inner body has a density close to mantle density which might suggest an origin as an eclogized body, formed by metamorphosis of lower crustal gabbro during the Caledonian orogeny. The difference in velocity and extent of the lower crustal bodies seems to be controlled by the Jan 
Mayen Lineament, suggesting that the lineament represents a pre-Caledonian structural feature in the basement.

Keywords: Møre Margin; ocean bottom seismometers; 3D density modelling; Jan Mayen Lineament.

\section{Introduction}

The Early Eocene continental break-up between Greenland and Eurasia occurred almost 300 km from the present day coastline of the mid-Norwegian Møre Margin. Today this $300 \mathrm{~km}$ transect, from the continent-ocean boundary to the Norwegian coast, is dominated by a 12-15 km deep sedimentary offshore basin (Raum, 2000). Onshore we find some of the steepest and most prominent mountain peaks in the Norwegian mountain chain (Redfield and Osmundsen, 2013). This transition from 12-15 km deep sedimentary basins offshore to $2 \mathrm{~km}$ high mountain range onshore takes place within a distance of only $150 \mathrm{~km}$. This rapid transition in crustal morphology makes the Møre Margin an ideal region for studies of onshore-offshore relationships and the evolution of differential topography.

As part of the TopoScandiaDeep project (Maupin et al., 2013), in which the lithospheric structures of southern Norway are studied, three ocean bottom seismometer (OBS) profiles with deep seismic wide-angle reflection and refraction data were acquired in the Møre Basin in May/June 2009. Two of the offshore profiles were continued onshore with land stations (Fig. 1).

The velocity and thickness of the onshore continental crust in southern Norway have been studied recently in the Magnus Rex experiment, a seismic refraction experiment with controlled sources (Stratford and Thybo, 2011; Stratford et al., 2009) and from teleseismic receiver functions (Frasetto and Thybo, subm.; Svenningsen et al., 2007). During this study the land stations of Profile 1 were deployed as an extension of the SE-NW trending profile across southern Norway in the Magnus Rex experiment (Weidle et al., 2010). The hydrocarbon exploration activity provides extensive documentation of the upper sedimentary section of the Mid-Norwegian Margin. The deeper part of the basin, representing the preCenomanian sedimentary succession and the basement structures, are less well documented. Previous geophysical studies with expanded spread profiling (ESP) (Olafsson et al., 1992), OBS-profiles (Mjelde et al., 2009b; Raum, 2000) and potential field data (Ebbing et al., 2006a; 
Reynisson, 2010; Reynisson et al., 2009) have increased our understanding of the basin evolution.

A common feature of volcanic continental margins is the presence of high-velocity lower crustal bodies (LCB), interpreted as magmatic intrusions / underplating (White et al., 2008). These features have been observed on the outer Vøring Margin (Mjelde et al., 2001); on the Møre Margin (Olafsson et al., 1992); and on the Rockall Plateau (White et al. (1987).

LCBs can also represent remnants of metamorphosed igneous rocks such as eclogite (Mjelde et al., 2012). At the inner flank of the Møre Basin, Olafsson et al. (1992) observed a LCB, which they interpret as remnants of Caledonian eclogite. The possible presence of eclogite is important for two reasons: 1 . The seismic Moho (P-wave velocities above $8 \mathrm{~km} / \mathrm{s}$ ) will represent the top of the lower crust, not the top of the mantle (Mjelde et al., 2009b). Thus, knowledge about such bodies is crucial for crustal scale geological and dynamical modeling (Mjelde et al., 2012). 2. There may be a link between eclogite bodies and the Caledonian suture zone on the Mid-Norwegian Margin.

Some key objectives addressed within this study are to: 1 . Study the differences in crustal structure between the two onshore-offshore profiles. 2. Map the possible coastal continuation of the LCB which, in previous studies (Mjelde et al., 2009b), have been observed in the outer Møre Basin. 3. Investigate the interplay between the Jan Mayen Lineament and the distribution of the LCB. 4. Discuss geological interpretations of the LCB.

\section{Geology}

The Møre Margin comprises the Møre Basin and the Møre Marginal High and is located south of the more intensively geologically and geophysically studied Vøring Margin (Fig. 1). The Møre Basin is a deep regional Cretaceous sedimentary basin which is located landward of the Møre Marginal High (Brekke et al., 2001; Gomez et al., 2004). While the geology of the Møre and Vøring Marginal Highs are dominated by Early Tertiary flood basalts, the Møre and Vøring basins dominantly originate from the period of Late Jurassic-Early Cretaceous intracontinental extension and rifting (Gomez et al., 2004). The Møre Basin is separated from the Vøring Basin by the Jan Mayen Lineament (Fig. 1). The Slørebotn Sub-basin, which is located on the landward side of a row of highs, is located in the easternmost part of the Møre Basin at the SW extension of the regional Hitra-Snåsa-Fault (Mørk and Johnsen, 2005). To the west, the Møre Basin is bounded by the Faeroe-Shetland Escarpment along the Møre Marginal High (Blystad et al., 1995). 
The Jan Mayen Lineament has partly controlled the post-Caledonian tectonic activity in the area and constitutes a boundary between the major structural provinces (Blystad et al., 1995). The Jan Mayen Lineament is defined by a distinct shift of basin axis and basin flanks. The Jan Mayen Lineament may also coincide with the southern boundary of the Trøndelag Platform (Fig. 1).

Another feature which is believed to have played an important role in the development of the mid-Norwegian Margin is the Møre-Trøndelag Fault Complex (Fig. 1). Gabrielsen et al. (1999) conclude that the Møre-Trøndelag Fault Complex is a long-lived and deep-seated zone of weakness, which has influenced and caused perturbation of regional stress fields of MidNorway during several periods. The Møre-Trøndelag Fault Complex strikes ENE-WSW, and parallels the coastline of Norway at its northeastern end (Gabrielsen et al., 1999). It continues offshore along the southern margin of the Møre Basin and into the west Shetland Basin (Fig. 1) (Brekke and Riis, 1987). The Vøring Basin was tectonically active during Tertiary time. In contrast, the Møre Basin was generally tectonically quiet throughout the Cretaceous and Tertiary periods, experiencing mainly continuous subsidence (Blystad et al., 1995). The reason for this difference might be that the Jan Mayen Lineament acted as a tectonic barrier (Brekke, 2000). However, the structural expression of Late Cretaceous and earliest Tertiary tectonics may be hidden under the wide area of lavas on the Møre Marginal High and the landward zone of "inner flows" (Blystad et al., 1995). After breakup the margin became part of a regional compressive regime giving rise to a number of intra-basin inversion features off Norway and on the margin farther south (Lundin and Doré, 2002). The compressive movements in the Møre Basin seem to be concentrated along the Jan Mayen Lineament, where the Ormen Lange Dome, and a number of other similar domes are situated en echelon along the lineament (Doré et al., 2008).

\section{Data and methods}

\subsection{Data acquisition}

The data were acquired using a seismic source which consisted of four equal sized $1200 \mathrm{inch}^{3}$ air-guns with a total volume of 4800 inch $^{3}$ (78.6 liters). The shooting interval was approximately 200 meters. The shooting was controlled by a GECO gun controller (GUNCO) and a Differential Global Positioning System (DGPS). The OBS-instruments were provided 
by Hokkaido University, Japan and IFM GEOMAR, Germany (Bialas and Flueh, 1999). The Japanese instruments consisted of 3 geophones while the German instruments were 4-channel, with 3 geophones and 1 hydrophone. The spacing between the OBS instruments was 10-12 km in the landward end (OBS1-4; Fig. 1); 15-20 for the instruments in the middle of the Møre Basin (OBS5-10); and $\sim 25 \mathrm{~km}$ for the westernmost instruments (OBS10-16). OBS instruments were deployed at depths ranging from $83 \mathrm{~m}$ to $2456 \mathrm{~m}$ (Fig 2). The spacing between land station instruments was approximately $1 \mathrm{~km}$. Reftek 125 (Texan) instruments, provided by the University of Copenhagen, Denmark were used as land stations with $4.5 \mathrm{~Hz}$ vertical component geophones. Land shots for lines 1 and 2 were $250 \mathrm{~kg}$ and $80 \mathrm{~kg}$ charge size, respectively.

\subsection{Data processing}

The OBS and land station instruments were constantly recording data during the period of seismic shooting. Based on data from the gun controller, the exact timing of the air gunfirings was used to cut the continuous recordings into separate traces of 60 seconds length. The next step was time-correction performed in order to correct for the possible drift of the source clock and receiver clocks. After conversion of the records to SEGY format the processing routines include in-line relocation of the ocean bottom receivers (due to drifting while sinking to the seabed), 2-5-15-20 Hz band-pass filtering (mostly for removal of the noise generated by current, which is typical of low frequency), automatic gain control (to boost the far-offset signal) and $8 \mathrm{~km} / \mathrm{s}$ travel-time reduction (to obtain nearly flat Moho refracted arrivals and shallow slope of crustal arrivals).

\subsection{Seismic modeling}

\subsubsection{Starting model}

Industrial multichannel seismic reflection (MCS) data from the Norwegian Petroleum Directorate's database were used to construct the starting models of sedimentary structures. Profile 1 was constructed along the NPD-STOR-85 line (Fig. 2a), while Profile 2 was developed along a composite line comprising the three MCS lines: GOM 95-411, NPD-MB92-12 and NPD-MB-92-18 (Fig. 3b). Profile 3, which in this study is mainly used as a tieprofile between the two dip-profiles, is not parallel to any available MCS line. Therefore a starting model was constructed from a compilation of multiple MCS data sets: SG9113, 
MM95, MMI97, ST8705, ST8707, SG9308 and NPD-STOR-85 (Fig. 3c). The three starting models have been depth converted using velocities typical for sediments at this depth and age in nearby regions (e.g. Breivik et al., 2011).

In the landward end, the sediment profiles clearly show the extensional geometry of the Møre Basin with multiple faults and down-faulted geometry defining structural elements such as the Sløreboth Sub-basin and the Gnausen High. The lines intersect the Møre Basin in a NE-SW direction, approximately parallel to the dominant rift axes (Lundin and Doré, 1997). The most prominent Cenozoic horizons, Base Upper Pliocene and Top Paleocene, can be followed continuously throughout almost the profiles. Base Tertiary is more uncertain, but can be followed from the coast until the eastward termination of Eocene basaltic sills (approximately km 35 on Profile 1, and km 75 on Profile 2). The Mesozoic horizons, Top Cenomanian and Base Cretaceous, are more difficult to follow. Top Cenomanian can be traced from the coast to approximately $\mathrm{km} 50$ and $\mathrm{km} 75$ for Profiles 1 and 2, respectively. The Base Cretaceous reflector (and older) is even more difficult to follow, but may be interpreted from the coast throughout Profile 1, and approximately to km 100 on Profile 2. The Base Cretaceous reflector generally lies very deep, and near the western end of the two profiles it is masked by Eocene flood basalt and basaltic sills. The Cretaceous and PreCretaceous sedimentary infill, however, defines a symmetrically shaped syncline from the coast to the Møre Margin.

\subsubsection{Rayinvr-layered based parameterization}

The initial starting models were calibrated by the new data with the combined forward modeling and inversion code Rayinvr (Zelt and Smith, 1992). This is a user controlled raytracing technique, where velocities and boundary depths are changed iteratively by trial-anderror until a reasonable fit between interpreted and calculated travel-time curves is achieved. The Rayinvr code allows for ray tracing of critically refracted, reflected and head waves. The software also allows use of multiple floating reflectors and for layers to be pinched out laterally (Zelt and Forsyth, 1994). The velocity model is constructed by lateral continuous layers with the geometry constructed by depth nodes. The velocity within each layer is defined by independent velocity nodes at the top and bottom. Consequently, each layer is represented by a velocity gradient. 
The strategy was to start with constructing a preliminary model based on the shotreceiver geometry and the depth-converted MCS data. In the inversion, the damped leastsquare method was used to update the model parameters chosen for adjustment (Zelt and Smith, 1992). The partial derivatives of travel-times with respect to model parameters are calculated using ray tracing. The partial derivates are calculated with respect to both the model velocities and the vertical position of the depth nodes (Zelt and Smith, 1992). The software includes a statistical tool whereby the goodness of the travel-time fit was measured by the misfit between the observed and modeled travel-times, defined by:

$\chi^{2}=\frac{1}{n} \sum_{i=1}^{n}\left(\frac{t_{0 i}-t_{c i}}{U_{i}}\right)^{2}$,

where $n$ is the number of picks for each phase, $t_{0}$ is the observed arrival time, $t_{c}$ is the calculated arrival time and $U$ is the estimated pick uncertainty. A $x^{2}$ around one indicates the best obtainable fit, while values of less than one indicate an over-fit of the model. When a satisfactory fit to the observed data was achieved, the layer was locked with respect to depth nodes and velocities. The procedure was repeated for successively deeper layers.

\subsubsection{Uncertainty, resolution and model non-uniqueness.}

The overall modeling philosophy has been to construct it smoothly to avoid overparameterization. Although the final model provided a satisfactory fit between observed and calculated travel-times ( $x$ 2 1), there are some limitations. The user-defined number of layers and velocity nodes, as well as the limitation of exploring the velocity-depth ambiguity of the lower crust (e.g. Korenaga, 2011), may lead to error in the final velocity model.

The goodness of the travel-time fit was measured by the $x^{2}$ (chi-squared) parameter. During the interpretation, the uncertainty suited for the quality of each arrival is assigned; normally the uncertainty is within \pm one cycle. When the signal to noise ratio is low or the amplitude is weak, the uncertainty can be higher. The quality of the sedimentary phases normally allows for picking with an estimated uncertainty of $\pm 50-70$ milliseconds; the estimated crustal uncertainty is \pm 80 -100 milliseconds for the crystalline crust, while the uncertainty of Moho and lower crustal arrivals normally are estimated to \pm 120 and 150 milliseconds, respectively. Some far offset mantle refractions are set to 200 milliseconds. For evaluation of the quality of the model, not only uncertainty, but also the resolution or ray coverage of the model is an important factor. Ray hits plots (Fig. 4) illustrate the qualitative differences between various parts of the model. The models are, naturally, better illuminated in the shallower parts 
compared to the deeper parts. Previous studies have shown that the general uncertainty for depth to the main crustal layers and Moho is estimated to $\pm 0.5 \mathrm{~km}$ in areas with very good data quality; $\pm 1.0 \mathrm{~km}$ were the data quality is poorer; and $\pm 1.5 \mathrm{~km}$ close to the ends of the profiles, whereas the uncertainty for the P-wave velocity is estimated to $\pm 0.05 \mathrm{~km} / \mathrm{s}$ with very good data quality; $\pm 0.1 \mathrm{~km} / \mathrm{s}$ where the data quality is poorer; and $\pm 0.15 \mathrm{~km} / \mathrm{s}$ close to the ends of the profiles (Mjelde et al., 1998; Mjelde et al., 2001; Mjelde et al., 2005; Mjelde et al., 2003; Raum et al., 2002)

\subsubsection{Synthetic seismograms}

In order to test and constrain our models we computed synthetic seismograms. The synthetic seismograms were created by solving the $2 \mathrm{D}$ acoustic wave-equation in the time-domain using finite-differences. The P-wave velocity model was gridded with a grid spacing of $25 \mathrm{~m}$. A density model was created from the velocity model using the velocity-density relations described by Brocher (2005). The input source wavelet was a Ricker wavelet with a central frequency of $5 \mathrm{~Hz}$. A time step of $0.001 \mathrm{~s}$ was used in the simulations. The grid was extended on the top and bottom, and on each side, with 20 points wide absorbing layers. As a result, no free-surface multiples were modeled. We applied seismic reciprocity in our simulations; hence each seismogram was created by applying the source wavelet at the OBS position, and by calculating the wave-field at the shot positions. This is valid in acoustic simulations and results in a significant reduction in computational cost.

\subsection{Density modeling}

The velocity model has been integrated in the pre-existing 3D density model of the Møre margin from (Reynisson, 2010; Reynisson et al., 2010). The 3D model was defined using the 3D modelling package IGMAS+ (Interactive Graphical Modelling Application System). The system uses polyhedrons with triangulated surfaces to approximate bodies of constant density and/or susceptibility, whose geometry is defined by a number of parallel vertical modelling sections. The system then calculates the potential field effect of the model at a designated station location (Götze and Lahmeyer, 1988; Schmidt et al., 2011).

The orientation of the vertical section was parallell to Profile 1 and 2 , which made it straightforward to adjust the model geometry accordingly. Profile 3 was modelled by checking the consistency with Profile 1 and 2 at the cross-points and by adjusting the model geometry in a 3D space by adjusting multiple 2D profiles. 
Fortunately, in general, only minor modifications to the 3D model of Reynisson (2010) had to be done. The main changes were for the deep structure at Moho level and the extension of the LCB. Figure 3a shows the location of the three OBS profiles in relation to the Bouguer gravity anomaly (Andersen et al., 2010; Olesen et al., 2010). The trend of the Bouguer anomaly reflects the deeper geometry of the margin, and the increase in crustal thickness from the oceanic domain to mainland Norway. Clearly, modeling of the OBS profiles is only possible by respecting the 3D geometry of the margin, in particular for the coast parallel profile. For more details on modeling procedure and 3D model set-up, see (Reynisson, 2010).

\section{Results}

\subsection{Sedimentary sequences}

\subsubsection{Profile 1}

All 16 OBS deployed along Profile 1 contained data. The quality varied from an interpretable signal range of $20 \mathrm{~km}$ (OBS 104) up to $160 \mathrm{~km}$ (OBS 102). The sedimentary successions are well illuminated by the OBS instruments (Table 1).

The Cenozoic sediments $\left(\mathrm{Ps}_{1}\right)$ and the Cretaceous / pre-Cretaceous $\left(\mathrm{Ps}_{2}\right)$ are observed on 11 OBS instruments along Profile 1. The average P-wave velocity of the $\mathrm{Ps}_{1}$-phase and $\mathrm{Ps}_{2}$-phase are approximately $2.2 \mathrm{~km} / \mathrm{s}$ and $4.1 \mathrm{~km} / \mathrm{s}$, respectively. OBS 105 and 102 indicate observed sediment velocities of approximately $4.5 \mathrm{~km} / \mathrm{s}$. Some reflections within the sedimentary succession are observed: The Base Cretaceous reflector was observed on OBS 115 (Fig 6b), 111, and 110, while pre-Cretaceous reflections were observed on OBS 113, 112 and 111.

The maximum depth of the total sedimentary succession in the mid-basin for Profile1, based on reflections from the top of the crystalline basement (PgP), was found to be approximately $15 \mathrm{~km}$. However, refractions were not modeled for all layers within the midbasin sediments. Conversely, at the Møre Marginal High and in the coastal area, refraction arrivals permit better resolution of the velocity structure in the sedimentary successions and the upper crust. The PgP reflections, used for establishing the depth to the crystalline basement (Table 1), are observed on instruments 113, 110 and 107. 


\subsubsection{Profile 2}

Data was acquired by 13 of 16 OBS instruments deployed along Profile 2 . Three of the OBS instruments (203, 209 and 212) were malfunctioning or contained data of marginal quality. The maximum offset of the observed phases varies between $20 \mathrm{~km}$ (OBS201) and more than $150 \mathrm{~km}$ (OBS205). Seismic phases from the Cenozoic sediments $\left(\mathrm{Ps}_{1}\right)$ were observed on 7 instruments, and on 8 and 3 instruments, respectively, from the Cretaceous $\left(\mathrm{Ps}_{2}\right)$ and older $\left(\mathrm{Ps}_{3}\right)$.The average velocity of the $\mathrm{Ps}_{1}$-phase is $2.1-2.2 \mathrm{~km} / \mathrm{s}$. The average velocity for the $\mathrm{Ps}_{2}$ phase is $4.5 \mathrm{~km} / \mathrm{s}$, while we model velocities of approximately $5.3 \mathrm{~km} / \mathrm{s}$ in the pre-Cretaceous sediments $\left(\mathrm{Ps}_{3}\right)$. Although the refractions only cover the upper part of the pre-Cretaceous sediment layer, the information constrains the velocity profile throughout the total sedimentary succession down to the crystalline basement. Based on this velocity profile, together with the reflections from the basement (PgP), we established a model demonstrating the depth and velocity of the total sediment succession. There are no observations of any intra-sedimentary reflection (Table 2). Since the overall data coverage is limited between OBS 214 and 208 in the mid-Møre Basin, the seismic profile of the sediment successions in this part of the model is less well documented.

\subsubsection{Profile 3}

All 11 OBS instruments deployed on Profile 3 acquired data. The general quality of the seismograms is good. Traveltime can readable picked on most of the seismic sections. The upper part of Profile 3 is well illuminated throughout the whole sedimentary succession (Table 3). For most of the sediment layers, velocity is constrained by refraction arrivals with the exception of the pre-Cretaceous package between $\mathrm{km} 75$ and km 120. On the Trøndelag Platform there is a relatively thin sediment cover of 1.2-1.3 km thickness over the bedrock. The velocity of these sediments is approximately $2.7-3.0 \mathrm{~km} / \mathrm{s}$ close to the seabed and approximately 3.3-3.5 km/s near the bedrock. This is significantly higher than in sediments on comparable depth in the Slørebotn Sub-basin, farther south. Here we find a lower sediment velocity of $1.6-1.7 \mathrm{~km} / \mathrm{s}$ close to the seabed and $2.1-2.3 \mathrm{~km} / \mathrm{s}$ at the bottom of the package. In the Slørebotn Sub-basin, the thickness of the Paleogene sediments is estimated to be between 0.9-1.8 km with a velocity of approximately $2.6 \mathrm{~km} / \mathrm{s}$. The Cretaceous sedimentary layer is approximately $4.2 \mathrm{~km}$ thick and reaches a maximum depth of $6 \mathrm{~km}$ at $\mathrm{km} 180$ with a velocity of approximately $3.2 \mathrm{~km} / \mathrm{s}$ at the top and $4.6 \mathrm{~km} / \mathrm{s}$ at the bottom. The velocity in the preCretaceous sedimentary succession of 5.0 and $5.2 \mathrm{~km} / \mathrm{s}$ at the top and bottom is constrained 
only by the refraction phase observed on OBS 303 to between 5.0 and $5.2 \mathrm{~km} / \mathrm{s}$ at the top and bottom, respectively.

\subsection{Crystalline basement, LCB and upper mantle}

\subsubsection{Profile 1}

Refractions from the crystalline basement are observed on all land stations in addition to OBS 116, 115, 105, 102 and 101 (Fig. 6b). Below the Møre Marginal High, the velocity of the crystalline basement varies between $6.1 \mathrm{~km} / \mathrm{s}$ in the top and $6.6 \mathrm{~km} / \mathrm{s}$ in the bottom. Reflections from top of the crystalline crust are observed on OBS 113, 110 and 107. No Pgphases are observed in the mid-basin area. The upper part $(0-12 \mathrm{~km})$ of the crust is well illuminated from OBS 105 and landward ( km 200-422). The velocity in the upper part of the crust is $5.8-6.2 \mathrm{~km} / \mathrm{s}$. One of the key observations on this profile is the middle crust reflector (PgP) (Fig. 6b). Reflections from this boundary are observed on 8 instruments; OBS 110, 108, 106, 105 and on land stations; 6021, 6031, 6039 and 6050. The velocity at the base of the upper crust is between 6.1 and $6.8 \mathrm{~km} / \mathrm{s}$. We observe reflections from a boundary in the western end of the profile on OBS 115 (Fig. 6b) and 112. These reflections are, however, interpreted to originate from the top of the outer LCB (Fig. 6c). Reflections from the base of the LCB/ Moho are observed at OBS 116 and 111. The P-wave velocity in the LCB is estimated to 7.2-7.3 km/s, inferred from the reflections from the base of the LCB. The Moho reflections (PmP) are observed on numerous instruments: OBS 116 and 111, and on land stations 6039, 6050, 6100, 6115, 6120, 6133, and 6138 (e.g. Fig. 7b, e). The westernmost instrument recording an observable Pn-phase is land station 6031 (Fig. 7b). This phase is additionally observed on land stations 6039, 6120, 6133 and 6138. On Profile 1 we observe a steep deepening in Moho depth from about $20 \mathrm{~km}$ in the middle of the Møre Basin to about 35 $\mathrm{km}$ under the coast. The deepening occurs over about $150 \mathrm{~km}$ distance. The dip of the Moho is steeper than farther north, on the Trøndelag Platform, where similar deepening occurs over about 200 km distance (Breivik et al., 2011).

\subsubsection{Profile 2}

In the western part of the profile OBS 216-214 recorded refractions from a layer interpreted as flood basalts (Fig. 8b). The Eocene break-up related to flood basalt is well documented by other authors, e.g. Mjelde et al. (2009b). The thickness of the layer with flood basalt is $\sim 2 \mathrm{~km}$. The velocity of the flood basalt is approximately $5.4 \mathrm{~km} / \mathrm{s}$ in the western end, gradually 
decreasing to $4.3 \mathrm{~km} / \mathrm{s}$ towards the east. On OBS 215 (Fig. 8b) and 208 we observe a reflection from the crystalline basement. The velocity in the crust, based on refractions observed on OBS 214, is 6.2-6.6 km/s. OBS 205 recorded the highest quality offshore data, with data extending to km 150 (Fig. 8b). The observed refractions from the crystalline basement indicate a lateral variation of velocity between 6 and $7 \mathrm{~km} / \mathrm{s}$ in the upper crust, from $\mathrm{km} 190$ to $\mathrm{km}$ 230. On the landward side of the instrument we observe a flat, rather weak reflector. This phase is modeled as a crustal refraction and a head wave was used for ray tracing. On the land stations we observe an almost continuous refraction from the basement (Pg). In contrast to Profile 1, we do not observe any intra-crustal refraction on Profile 2. The velocity structure of the crust is best resolved around the coast (Fig. 4b), in this area we observe strongest lateral velocity variation. The upper velocity is lowest (5.8-5.9 km/s) between $\mathrm{km} 180$ and 240. At km 250 we observe the highest velocity of around $6.6 \mathrm{~km} / \mathrm{s}$ at the top and $7.3 \mathrm{~km} / \mathrm{s}$ at the bottom of the layer. The thickness of the crystalline crust above the outer LCB varies from $7 \mathrm{~km}$ to $4 \mathrm{~km}$. Refractions from the outer LCB are observed on OBS 216, providing a direct measure of the velocity of this body of approximately $7.6 \mathrm{~km} / \mathrm{s}$. Reflections from the top of the outer LCB $\left(\mathrm{P}_{\mathrm{LCB} 1} \mathrm{P}\right)$ are observed on OBS 216,215 and 211 (Fig. 8b). A reflection from Moho (PmP), which is the bottom of the LCB, is observed on OBS 214. The depth to the Moho below km 0-200 of Profile 2 is approximately $20 \mathrm{~km}$, which is in agreement with the results found by Mjelde et al. (2009b). However, the depth of the Moho between km 0-60 is not documented by our seismic data. We observe PmP-phases on OBS 211, 210 and 208. On OBS 208 we also observe a reflection from the crystalline basement (PgP) and presumably a reflection from the top of a second lower crustal body $\left(\mathrm{P}_{\mathrm{LCB} 2} \mathrm{P}\right)$. A PmP-phase is observed on OBS 206 with the reflection point at approximately 19 $\mathrm{km}$ depth at $\mathrm{km} 200$. The velocity of the LCB is $7.6-7.7 \mathrm{~km} / \mathrm{s}$ at the top and $8.0 \mathrm{~km} / \mathrm{s}$ at the bottom. The length of the inner LCB is approximately $100 \mathrm{~km}$, from the mid-Møre Basin to the coast. The depth ranges from $\sim 17 \mathrm{~km}$ to $\sim 37 \mathrm{~km}$. The far-offset land stations; 7063, 7070, 7079 and 7084 recorded deep reflections, most likely from a lower crustal reflection (Fig. 9f). These reflections have been modeled as floating reflectors ( $\left.\mathrm{P}_{\text {FLOATING }}\right)$.

\subsubsection{Profile 3}

The velocity structure of the crust along the inner flank of the Slørebotn Sub-basin is well resolved due to a clear and persistent Pg-phase on most of the seismograms of Profile 3 (Fig. 10b). The Pg-phase, however, is somewhat difficult to follow in the transition area between 
the platform and basin. The PmP-phase, of varying amplitude and continuity, is observed on all seismograms (Figs 5b, 10b). The Pn-phase is observed only on the four instruments on the Trøndelag Platform (OBS 313-310). These seismograms show a clearly defined Pg-phase and relatively weak Pn-phase (Fig. 10b). On the Trøndelag Platform we observe velocities of 6.0$6.1 \mathrm{~km} / \mathrm{s}$ at the top of the crust and $6.6-6.7 \mathrm{~km} / \mathrm{s}$ at the bottom of the crystalline crust. The corresponding velocities in the Slørebotn Sub-basin are 6.2-6.4 km/s at the top and $6.8-7.1$ $\mathrm{km} / \mathrm{s}$ at the bottom. The only exception to this observation is found in the area between $\mathrm{km} 80$ and 100 where the Klakk Fault Complex intersects the Møre Trøndelag Fault Complex. Here we observed top crustal velocities of $5.6-5.8 \mathrm{~km} / \mathrm{s}$. The crust is approximately $26 \mathrm{~km}$ thick under the Trøndelag Platform where we observe two floating reflectors at different levels at 5$7 \mathrm{~km}$ depth at 18-20 km depth. Below the platform-basin transition zone we model a steep floating reflector at 5-15 km depth. We observe the LCB underneath the Slørebotn Sub-basin. The thickness of the LCB is 4-6 km and the velocity is $7.7 \mathrm{~km} / \mathrm{s}$ at the top and $8.0 \mathrm{~km} / \mathrm{s}$ at the bottom of the layer. On Profile 3 the Moho depth is approximately $28 \mathrm{~km}$ under the Trøndelag Platform and $30 \mathrm{~km}$ below the Slørebotn Sub-basin.

\subsubsection{D-density model}

The density modeling of the velocity models supports the seismic interpretation. Densities are initially determined according to velocity-density conversion and borehole logs assembled by Reynisson (2010). To adjust the gravity effect of the 3D model, only minor changes from the seismically defined geometry were needed. The changes of the geometry are within the uncertainties of the seismic horizons. Notably, we model the LCB with a density of 3100 $\mathrm{kg} / \mathrm{m}^{3}$ for the outer LCB, and $3300 \mathrm{~kg} / \mathrm{m}^{3}$ for the inner LCB (Figs 11-13). In Figure 12 and 13 we show also the gravity field for an inner LCB with $+/-200 \mathrm{~kg} / \mathrm{m} 3$, which demonstrated the misfit to the observed data. This gravity misfits cannot easily be compensated by changing the geometry/density of other crustal structures as they are well constrained by the OBS profiles.

For the entire 3D model, the deviation between the gravity effect of the model and the observed gravity field is $<10 \mathrm{mGal}$ with the exception of some local structures, which cannot be addressed with the resolution of the model ( $\sim 10 \mathrm{~km}$ in horizontal direction). Along Profile 1 (Figure 11) small misfits exist for the central high, which can be explained by a more heterogeneous near surface density distribution than modeled here. Along Profile 2 (Figure 12) similar short wavelength misfit exists, if the density of the inner and outer LCB is varied. 
Profile 3 (Figure 13) cannot be modeled as a simple 2D model (see Figure 3a) as its strike direction is parallel to the trend of the gravity field and the coast. The profile is located directly above the transition from shallow Moho on the shelf to deep Moho beneath the coastline, and hereby close to the landmost extent of the inner LCB. Clearly, the profile shows the transition from a non-existing (or thin) inner LCB in the northern part to the presence of an inner LCB in this part of the profile. However, the density of the inner LCB is close to the mantle density. In the gravity field, this increase of lower crustal mass is not directly observed as the effect of the inner LCB is compensated by the thick sedimentary sequence, which provides isostatic equilibrium.

\section{Discussion}

\subsection{Upper part}

\subsubsection{Flood basalt}

Profile 1 does not show indications for the presence of break-up related flood basalt as observed on the intersecting profiles 2-99 and 3-99 (Mjelde et al., 2009b). It has been proposed that the extent of the Eocene flood basalt varies along the continental break-up zone, with decreasing magmatic activity away from the Icelandic hot-spot (Eldholm et al., 2002). In addition, it appears that proximity to the Jan Mayen Fracture Zone has been of importance because of lateral lithospheric heat transport and cooling of the magmatic source region (Berndt et al., 2001). The absence of flood basalts in Profile 1 seems to confirm this interpretation. Berndt et al. (2001) describe this region as a transform margin, with shallow intrusions and only a small area of inner flows. The coinciding MCS profile NPD-STOR-85 also shows no indication of flood basalts in the western end. Contrary the findings of Mjelde et al. (2009b), who found indications for some amount of extrusives. This discrepancy suggests that the thickness of possible flood basalts is close to the resolution limit in this northern corner of the Møre Basin.

In Profile 2 we observed refractions from a layer which may contain flood basalt on OBS 216-214 (Fig. 8b). The velocity in this $2 \mathrm{~km}$ layer gradually decreases from $5.4 \mathrm{~km} / \mathrm{s}$ close to the COT, to $4.3 \mathrm{~km} / \mathrm{s}$ where it wedges out landwards. We also observe a gradual decrease in velocity eastwards from $\mathrm{km} 30$,most likely due to increasing content of sediments from km 30 until the basalt pinches out at km 60 or because the basalt layer solidified very fast. The modeled thickness and landward extent of this layer are consistent with the observations of Mjelde et al. (2009b). These authors, however, inferred a lower velocity of 
3.8-4.0 km/s in the flood basalt layer. The velocity is consistent with the P-wave velocity in basalt (Christensen and Mooney, 1995). There is, however, considerable uncertainty concerning interpretations of lithology based solely on the P-wave velocity (Holbrook et al., 1992).

\subsubsection{Sedimentary section}

On Profile 1 the deepest diving waves in the sedimentary section (on OBS 105) are traced to $\sim 8 \mathrm{~km}$ depth with an inferred velocity of $4.3-4.5 \mathrm{~km} / \mathrm{s}$. This layer is interpreted as preCenomanian sediments. The boundary between Cenomanian and Cenozoic sediments is found at $\sim 5 \mathrm{~km}$, which is consistent to the findings of Raum (2000). On Profile 2 the flood basalt overlies the Early Tertiary, Cretaceous and pre-Cretaceous sediments. Due to the high velocities in the basalt, we do not have any direct velocity observation of these layers. Further east (OBS 214), the basalt layers pinches out such that refractions from sediments occur.

The deepest sedimentary refractions observed on Profile 2 (on OBS 214 and 202) are interpreted as pre-Cretaceous sediments. The velocity is $5.2-5.4 \mathrm{~km} / \mathrm{s}$ in the western part and 5.5-5.8 km/s in the Slørebotn Sub-basin. The high velocities $(5.5-5.8 \mathrm{~km} / \mathrm{s})$ in the Slørebotn Sub-basin (Fig. 12b) are most likely caused by Devonian sediments accumulated in a deep sedimentary basin or in half-grabens on the strongly faulted inner flank (Fig 2a, b).

Profile 3 consists of both narrow platform areas, on the Trøndelag Platform, and a deep sedimentary basin in the Slørebotn Sub-basin. The observation of high-velocity sediments (2.7-3.0 km/s close to the seabed and 3.3-3.5 km/s close to the bedrock) indicates a higher degree of compaction in the sediments on the Trøndelag Platform than in the Slørebotn Sub-basin. The sediment velocities inferred from the sonic log of exploration well 6306/6-1 (Fig. 1) are in agreement with our modeling results. The main mechanism for the removal of young unconsolidated sediments on the Trøndelag Platform was erosion by PliocenePleistocene ice sheets. The position of the northeastern part of Profile 3 coincides with a prominent ice-stream route south of the Frøya High (Ottesen et al., 2005). The northeastern parts of Profile 3 probably therefore represent a scoured shelf, where most of the Cenozoic sediments have been scraped off by the ice-stream. In the Sløreboth Sub-basin, on the other hand, only the uppermost sediments have been removed by the ice-stream. During the retreat of the ice sheet, more sediment was deposited in the Slørebotn Sub-basin. We therefore find sediments with velocities between 1.5 and $1.7 \mathrm{~km} / \mathrm{s}$ in the basin of a type which is absent on the platform. 


\subsection{Crust and upper mantle}

\subsubsection{Upper crystalline crust}

The modeling of the western part of Profile 1 and 2 benefitted from three of the OBS lines ( 299, 3-99 and 4-99) published by Mjelde et al. (2009b). Profile 4-99 intersects Profile 1 approximately $5 \mathrm{~km}$ east of OBS 116, while Profile 3-99 intersects Profile 1 at approximately $\mathrm{km} 42$ (Fig. 1). The depth to the top of the crystalline basement is $5.5 \mathrm{~km}$ on $4-99$ and $8.2 \mathrm{~km}$ on 3-99, whereas the corresponding depths are $7.8 \mathrm{~km}$ and $12 \mathrm{~km}$ on Profile 1 . The depth to the base of the crust is $14 \mathrm{~km}$ on $4-99$ and $16 \mathrm{~km}$ on 3-99, corresponding to $15.7 \mathrm{~km}$ and 16.3 $\mathrm{km}$ on Profile 1 . The discrepancy between the models can partly be explained by the absence of flood basalt in Profile 1, as the presence of a shallow layer of flood basalt in a model will significantly influence the resolution of the deeper part. In addition, variable data quality, modeling strategy and different starting models will influence the results. However, the discrepancy of $3.8 \mathrm{~km}$ between Profile 3-99 and Profile 1 in depth to top of the crystalline crust must have an additional explanation. The modeled crystalline crust of Profile 3-99 is very rugged with depth varying between 8.2 and $14 \mathrm{~km}$. This strong lateral variance is not reflected in our smooth model (Fig. 6), and could hence reflect part of the explanation for the discrepancy. On Profile 2, the upper and lower velocity of 6.2 and $6.6 \mathrm{~km} / \mathrm{s}$, respectively, on the Møre Marginal High is consistent with the findings of Mjelde et al. (2009b). On Profile 399 and Profile 4-99, the depth to the top of the crust was 14 and $10.5 \mathrm{~km}$, respectively corresponding to our findings of 13 and $10.5 \mathrm{~km}$ (Fig. 12). The Moho depths along the two strike profiles (Fig. 12 and 13) are in accordance with the Moho depths observed in the Møre Basin by Fernandez et al. (2005). These authors observe a Moho depth of $13 \mathrm{~km}$ below the Møre Margin, a depth of $20 \mathrm{~km}$ in the mid-basin and deepening (Fernandez et al., 2005).

The geometry of the crystalline crust structure from the Møre Marginal High to the coast is generally similar to two parallel wide-angle seismic studies (Olafsson et al., 1992; Raum, 2000). The crystalline crust on Profile 1 and 2 is 7-8 km thick at the northwestern end, thinning gradually to a minimum of 3-5 km towards the basin center (Figs. 11 and 12). From the basin center towards the coast, the thickness of the crust gradually increases to about 25$30 \mathrm{~km}$. On Profile 2 ( km 230) we observe a large velocity difference with an upper crustal velocity of $5.8 \mathrm{~km} / \mathrm{s}$ and $7.1 \mathrm{~km} / \mathrm{s}$ at the base (Fig. 12). The relatively low upper crustal velocity is most likely due to the intersection of the Møre Trøndelag Fault Complex and 
thereby a strongly faulted crust with sediment-filled half-grabens. Over $90 \%$ of all the modeled Pg-rays of Profile 1 and 2 are from land stations. Hence, the velocity structure of the upper crust is considered more robust than its offshore part. The velocity variation for the upper crust onshore (5.8-6.2 km/s) is consistent with the models by Stratford and Thybo (2011). The observed lateral velocity variations are most likely caused by heterogeneities in the post-Caledonian bedrock.

There is a general trend of decreasing velocity in basement from the NE to the SW along Profile 3 (Fig. 13). This is most likely due to a change in lithology, with corresponding variation of P-wave velocity along the profile. We note that exploration wells penetrating the crystalline basement have revealed different basement compositions. Well 6305/12-2 (Fig. 1), penetrated Bathonian sediments and reached a low-grade metamorphic greenstone basement at the Gossa High, (Jongepier et al., 1996). On the western side of the Frøya High, well 6306/10-1 reached basement consisting of quartz diorite to monzonite below Bathonian Garn formation. In well 6408/12_U_01 in the northeastern part of the Froan Basin, the granitic basement underlying the Middle Jurassic sandstone is strongly weathered (Mørk and Johnsen, 2005). It is suggested by Mørk and Johnsen (2005) that this could indicate a basement boundary between the low-grade metamorphic Palaeozoic province of the Møre Trøndelag Fault Complex, and the Western Gneiss Region inside the Slørebotn Sub-basin.

\subsubsection{Intra-crustal reflections}

In contrast to our findings on Profile 1, neither Raum (2000) nor Olafsson et al. (1992) observe any mid-crustal reflector in their studies. However, several mid-crustal boundaries were proposed in a crustal scale wide-angle reflection and refraction seismic study carried out along the onshore continuation of Profile 1 (Stratford and Thybo, 2011). Although we do not observe any mid-crustal reflections southeast of approximately km 300 on Profile 1, there might be a connection between the mid-crustal reflector on Profile 1 and the crustal boundary at 22-23 km depth observed by Stratford and Thybo (2011). At the Trøndelag Platform Breivik et al. (2011) observe two intra crustal reflectors; one at 12-17 km depth and one at about 22-24 km depth. These authors observe approximately the same dome-shape of the reflector under the coast as we model for profile 1 (Fig 11). Likewise, in the study of Breivik et al. (2011), the dome-shaped structure is concurrent with a strong gravimetric anomaly (Fig. 3a). These two observations; the gravity anomaly and the difference in acoustic impedance, indicate the presence of a zone of different geology to the surroundings. The differences 
might be related to the fact that the mid Norwegian margin represents the edge of the Baltic Shield. The margins of cratons are heavily affected by deformation processes, island arc accretion and orogenesis (Wilson, 1968). Breivik et al. (2011) interpreted the intra-crustal reflector/gravity anomaly as igneous intrusions related to the Trans-Scandinavian Igneous Belt (1.8-1.65 Ga). On Profile 3 two intracrustal floating reflectors are observed below the platform (Fig. 13), but we do not observe the continuous floating reflector observed on the intersecting Profile 1 (Fig. 11). This might be due to the difference in shooting direction between the two profiles. In the foot wall between the Trøndelag Platform and the Slørebotn Sub-basin, at the intersection between the Klakk Fault Complex and the Møre-Trøndelag Fault Complex (Fig. 1), we observe a zone with low crustal velocity (5.5-5.8 km/s). We also observe a steep intra-crustal floating reflector which is semi-parallel to the foot wall. An alternative explanation could be that the velocities of $5.5-5.8 \mathrm{~km} / \mathrm{s}$ actually represent Devonian sediments, and that the floating reflector is the top of the crystalline basement.

\subsubsection{Lower crustal bodies}

Generally there are three main hypotheses concerning the nature of these bodies: 1 . Magmatic intrusives (e.g. Mjelde et al., 2003). The intrusives are most often associated with the major magmatic production during the Early Eocene continental break-up (e.g. Eldholm et al., 2002) preceded by the Late Maastrichtian rifting phase (Lundin and Doré, 1997). 2. Highgrade metamorphic mafic rocks (eclogites). According to this hypothesis, the lower crustal bodies may represent the crustal root of the Caledonian orogeny (Ebbing et al., 2006b; Gernigon et al., 2006; Gernigon et al., 2004; Mjelde et al., 2012), as also proposed for the southern Caledonian orogeny (Abramovitz and Thybo, 1998, 2000). 3. Serpentinites in the uppermost (petrological) mantle, analogue to the proposal of (Dean et al., 2000; Ren et al., 1998; Reston et al., 1996) for the Iberian Margin, where serpentinization of mantle peridotite may be caused by water penetration through an extensively thinned (normally $<5 \mathrm{~km}$ ) and fractured crust (Pérez-Gussinyé and Reston, 2001).

The two buried basement highs beneath the outer margin off Norway, the Møre and Vøring Marginal Highs, have been drilled and large amounts of Early Eocene volcanics have been documented (Eldholm et al., 2002). Most authors thus interpret the lower crustal bodies as magmatic underplating in this outermost part of the margin (e.g. Mjelde et al., 2009a).

Further eastwards, close to the COT, lower crustal bodies are observed both on both Profile 1 and 2. The shape of the outer LCB seems to correlate with the overlying basin, with 
a deepening of the LCB underneath the basin's deepest point (Fig 11a). We thus observed similar geometry to Olafsson et al. (1992) and Raum (2000). However, these authors observe a more landward extending LCB (to about km 220), with an increasing thickness of the LCB underneath the Vigra High (Fig 1). The depth of the LCB on 3-99 and 4-99 (Mjelde et al., 2009b) corresponds to our findings on Profile 1; the depth to the top and bottom of the outer LCB is found to be approximately $16 \mathrm{~km}$ and $19 \mathrm{~km}$, respectively (Fig. 11). Due to lack of refraction data, we have no direct information on the velocity within the LCB. Therefore, we cannot constrain the precise thickness of the LCB. The velocity determined from reflectionmoveout is solely an approximation of the average velocity within the layer, but we do find indications of lateral variation from $7.2 \mathrm{~km} / \mathrm{s}$ in the westernmost part to $7.6 \mathrm{~km} / \mathrm{s}$ at $\mathrm{km} 100$. Similar variations are reported from the Vøring Basin (Mjelde et al., 2003). These authors interpret the lateral velocity variations in terms of a heterogeneous mantle source.

On Profile 2, the depth to the base of the crust show slight difference to the findings of Mjelde et al. (2009b) who find $19 \mathrm{~km}$ on 3-99 and $15.5 \mathrm{~km}$ on 4-99, whereas our findings for the same points are 17 and $14 \mathrm{~km}$, respectively. Our velocity in the outer LCB (7.6-7.8 km/s) on Profile 2 is higher than the 7.2-7.3 km/s reported in the study of Mjelde et al. (2009b), and in other comparable studies of the Møre Basin (Olafsson et al., 1992; Raum, 2000). Our interpretation is based mainly on one refraction phase observed in the section for OBS 216; hence the observation must be considered as uncertain. However, velocities up to 7.6 -7.7 $\mathrm{km} / \mathrm{s}$ have been reported in magmatic underplating in the Vøring Basin (Mjelde et al., 2003; Raum et al., 2006). Assuming a normal (i.e. pyrolitic) source mantle Korenaga (2011) shows that the mantle potential temperature exerts dominant control on the thickness of igneous crust and its $P$-wave velocity. Generating a $4-5 \mathrm{~km}$ thick LCB with a velocity of $7.6-7.8 \mathrm{~km} / \mathrm{s}$ would, however, require unrealistic high mantle temperatures. Consequently, the observed velocity in the outer LCB of Profile 2 of 7.6-7.8 km/s might be explained by depleted mantle composition in terms of an elevated MgO content in the lower crustal mafic intrusions (e.g. Mjelde et al., 1997; Mjelde et al., 2009b). However, it could also indicate that high-grade metamorphic rocks to a certain degree are present, as suggested by several authors (Ebbing et al., 2006b; Gernigon et al., 2006; Gernigon et al., 2004).

The termination of the outer LCB at km 150 on Profile 1 coincides with the point where the intra-crustal reflector wedges out westwards (Fig. 11). The outer LCB on Profile 2 pinches out at approximately km 120 (Fig. 12). On Profile 2 we do not observe any intracrustal reflector. This could indicate differences in the geodynamic processes in the area around Profile 1 and 2, and that part of the observed outer LCBs have different origin. The 
interpretation of Olafsson et al. (1992) and Raum (2000) of a more landward extent of the outer LCB further north than observed in this study, is supported by volcanic plugs (the Vestbrona Formation) of olivine nephelinite dredged at $63^{\circ} 25^{\prime} \mathrm{N}, 6^{\circ} 45^{\prime} \mathrm{E}$ on the MidNorwegian continental shelf (Bugge et al., 1980) (Fig. 1). Prestvik et al. (1999) suggest that the source probably represents an enriched, low-temperature melting end member component of the North Atlantic (Icelandic) plume. Similar alkaline volcanic rocks are documented in the adjacent continental crust in east Greenland close to the termination of the Jan Mayen Fracture Zone (Brooks et al., 1979; Prestvik et al., 1999). Torske and Prestvik (1991) suggest that this spatial relation indicates that older continental fault systems acted as pathways for the mantle derived melt when the area was under extension and affected by the Iceland mantle plume. Eventually, the eastward extent of the intrusive complexes locally may be much greater than currently mapped (Planke et al., 2005). In addition to variation in the data quality, there may be several reasons why we do not observe the same landward extent of the outer LCB as Olafsson et al. (1992) and Raum (2000); for example presence of the Jan Mayen Lineament might have induced a decrease in melt generation. Although the Vestbrona Formation at $63^{\circ} 25^{\prime}$ is to the northeast of the proposed Jan Mayen Lineament, it might have been fed by local dikes (Torske and Prestvik, 1991). We observe a reflection from approximately $25 \mathrm{~km}$ depth at approximately $\mathrm{km} 150$ in the section for OBS 111. This is approximately $5 \mathrm{~km}$ deeper than the observations of Olafsson et al. (1992) and Raum (2000). Due to our limited data coverage in this area we have chosen to model this reflector as a floating reflector only, and not as an extension of the LCB. We cannot, therefore, rule out the possibility of a further landward extent of the LCB in our model as well.

East of the COT and the marginal highs, around the basin-centers, the crustal thickness is reduced considerably (Fernandez et al., 2005) due to the previous Jurassic and Cretaceous rifting episodes (e.g. Lundin and Doré, 1997). Hence, Eocene magmatic underplating, serpentinization and eclogites are conceivable hypotheses in this area (Peron-Pinvidic et al., 2012; Reynisson et al., 2009). Fichler et al. (2011) interpret a degree of serpentinization of the lower crust in the northern Viking Graben, based on magnetic data. However, in the outer part of the Møre margin magnetic modeling is not straightforward. Basalt extrusives dominate the magnetic field and prevent identification of a long-wavelength signal from the deep crust.. In an extensive review of these hypotheses, Mjelde et al. (2009a) favors the model of magmatic underplating emplaced mainly during the Eocene break-up, but these authors do not rule out the possibility for partly eclogized or serpentinized terranes as well. 
The velocity structure of the inner LCB on Profile 2 is $7.6-7.7 \mathrm{~km} / \mathrm{s}$ at the top and 8.0 $\mathrm{km} / \mathrm{s}$ at the bottom, and thereby lower than the $8.5 \mathrm{~km} / \mathrm{s}$ interpreted by Olafsson et al. (1992). The geometry of the inner LCB in our study is different from the LCB in the model of Olafsson et al. (1992). Our model suggests a dipping body along the transition from thinned crust to thicker crust onshore. The model of Olafsson et al. (1992) is based on observations at the end of their profile (Fig. 1) which only provides non-reversed coverage. Our observation is based on numerous refractions and reflections from multiple land stations, which may resolve more of the $2 \mathrm{D}$ geometry. The density of the inner LCB is similar to mantle material and, gravimetrically, the top of the inner LCB may represent the Moho. We may thus alternately consider the base of the inner LCB to be an upper-mantle reflection. However, if the geometry of the inner LCB is lower-crust related, as inferred by the seismic modeling, the reason for the observed seismic arrivals could be a partly eclogized body, with a bulk density of $3330 \mathrm{~kg} / \mathrm{m}^{3}$ and $\mathrm{Vp}$ of $7.7 \mathrm{~km} / \mathrm{s}$, instead of a solid continuous body. Onshore eclogites are quite abundant (Hacker et al., 2010), and both dip-profiles are crossing eclogites onshore (Robinson et al., 2003). Eclogite bodies have also been interpreted in the southern Caledonides (Abramovitz and Thybo, 1998, 2000). We thus favor the eclogite hypothesis for the inner LCB (Olafsson et al., 1992; Raum, 2000), mainly due to the relative thick crust and lack of observation of basalt.

\section{Conclusions}

We present three regional profiles on the mid-Norwegian margin based on modeling of new wide-angle seismic data. Two of the profiles cover the onshore-offshore transition, based on data acquired from land stations and OBSs. The profiles extend from the Western Gneiss Region, approximately $100 \mathrm{~km}$ onshore, to the Møre Marginal High, located approximately $300 \mathrm{~km}$ off the coast of mid-Norway. The third profile was a tie-profile with OBSs only, along the strike of the inner flank of the Slørebotn Sub-basin. On the tie-profile we observe a systematic variance in the P-wave velocity structure of the crust from $6.1-6.6 \mathrm{~km} / \mathrm{s}$ in the northeast to $6.3-6.8 \mathrm{~km} / \mathrm{s}$ in the southwest. This difference in P-wave velocity may reflect a change in lithology along this transect. In the Møre Basin we observed a sedimentary thickness of 12-15 km, underlain by a highly thinned continental crust. In one of the two dipprofiles we observe a prominent intra-crustal reflector close to the coast. We interpret this reflector as a remnant of the Caledonian orogeny. This observation suggests a different geodynamical history between the two dip-profiles. The extent of the lower crustal bodies, 
underlying the stretched continental crust, is different on between the two dip-profiles. We observe an outer LCB on the northern profile, which pinches out under the mid-Møre Basin. On the southern profile we observed both an outer and an inner LCB. We interpret the outer LCBs as mafic underplating related to the Early Eocene break-up, and the inner LCB as highgrade metamorphic remnants from the Caledonian orogeny. The onshore- to offshoretransition is $100-150 \mathrm{~km}$ wide and is marked by a prominent change in Moho depth from 18 to $40 \mathrm{~km}$ associated with a significant change in seismic velocity structure.

\section{Acknowledgments}

The data acquisition was funded by the Research Council of Norway (NFR) as part of the TopoScandiaDeep project. We would like to thank all the participating institutions and the crew at R/V Håkon Mosby. Ole Meyer, Asle Tveiterås, Dagfinn Snartemo, Stig Monsen and Aleksander Minakov from University of Bergen and Stephen A. Clark from University of Oslo are thanked for their contribution during the OBS acquisition. We also thank Anke Danowski, Wiebke Brunn and Stefan Moeller from IFM-Geomar, and Bent Ole Ruud from the University of Bergen, for acquisition and processing of the OBS-data. Wanda Stratford, Ingrid Anell, Mohammed Soliman, Martin Mehlsen, Tobias Stål from University of Copenhagen and Andreas Koelher (University of Oslo) are acknowledged for acquisition and processing of the land station data. GMT (Wessel and Smith, 1998) was used to generate many of the figures.

\section{References}

Abramovitz, T., Thybo, H., 1998. Seismic structure across the Caledonian Deformation Front along MONA LISA profile 1 in the southeastern North Sea. Tectonophysics 288, 153-176. Abramovitz, T., Thybo, H., 2000. Seismic images of Caledonian, lithosphere-scale collision structures in the southeastern North Sea along Mona Lisa Profile 2. Tectonophysics 317, 2754.

Andersen, O.B., Knudsen, P., Berry, P.A.M., 2010. The DNSC08GRA global marine gravity field from double retracked satellite altimetry. Journal of Geodesy 84, 191-199.

Berndt, C., Planke, S., Alvestad, E., Tsikalas, F., Rasmussen, T., 2001. Seismic volcanostratigraphy of the Norwegian Margin: constraints on tectonomagmatic break-up processes. Journal of the Geological Society 158, 413-426.

Bialas, J., Flueh, E.R., 1999. Ocean Bottom Seismometers. Sea Technology 40, 41-48.

Blystad, P., Brekke, H., Færseth, R.B., Larsen, B.T., Skogseid, J., Tørudbakken, B., 1995. Structural elements of the Norwegian continental shelf. Part II: The Norwegian Sea region. Norwegian Petroleum Directorate Bulletin 8, 45. 
Breivik, A.J., Mjelde, R., Raum, T., Faleide, J.I., Murai, Y., Flueh, E.R., 2011. Crustal structure beneath the Trøndelag Platform and adjacent areas of the mid-Norwegian margin, as derived from wide-angle seismic and potential field data. Norwegian Journal of Geology 90, 141-161.

Brekke, H., 2000. The tectonic evolution of the Norwegian Sea Continental Margin with emphasis on the Vøring and Møre Basins, in: Nottvedt, A., et al (Ed.), Dynamics of the Norwegian Margin. Geological Society, Special Publications, London, pp. 327-378.

Brekke, H., Riis, F., 1987. Tectonics and basin evolution of the Norwegian shelf between $62^{\circ}$ $\mathrm{N}$ and $72^{\circ} \mathrm{N}$. Norsk Geologisk Tidsskrift 67, 295-321.

Brekke, H., Sjulstad, H.I., Magnus, C., Williams, R.W., 2001. Sedimentary environments offshore Norway - an overview, in: Martinsen, O.J., Dreyer, T. (Eds.), Sedimentary environments offshore Norway-Paleozoic to resent. NPF Special Publications. Elsevier Science Ltd, pp. 7-37.

Brocher, T.M., 2005. Empirical relations between elastic wavespeeds and density in the Earth's crust. Bulletin of the Seismological Society of America 95, 2081.

Brooks, C.K., Pedersen, A.K., Rex, D.C., Undersøgelse, G.G., 1979. The petrology and age of alkaline mafic lavas from the nunatak zone of central East Greenland. Grønlands geologiske undersøgelse.

Bugge, T., Prestvik, T., Rokoengen, K., 1980. Lower Tertiary volcanic rocks off Kristiansund - Mid Norway. Marine geology 35, 277-286.

Christensen, N.I., Mooney, W.D., 1995. Seismic velocity structure and composition of the continental crust: a global view. Journal of Geophysical Research 100, 9761-9788.

Dean, S., Minshull, T., Whitmarsh, R., Louden, K., 2000. Deep structure of the ocean continent transition in the southern Iberia Abyssal Plain from seismic refraction profiles: The IAM - 9 transect at $40^{\circ} 20^{\prime}$ N. Journal of Geophysical Research: Solid Earth (1978 2012) 105, 5859-5885.

Doré, A.G., Lundin, E.R., Kusznir, N.J., Pascal, C., 2008. Potential mechanisms for the genesis of Cenozoic domal structures on the NE Atlantic margin: pros, cons and some new ideas. Geological Society London Special Publications 306, 1.

Ebbing, J., Lundin, E., Olesen, O., Hansen, E.K., 2006a. The mid-Norwegian margin: a discussion of crustal lineaments, mafic intrusions, and remnants of the Caledonian root by 3D density modelling and structural interpretation. Journal of the Geological Society 163, 47-59. Ebbing, J., Lundin, E., Olesen, O., Hansen, E.K., 2006b. The mid-Norwegian margin: a discussion of crustal lineaments, mafic intrusions, and remnants of the Caledonian root by 3D density modelling and structural interpretation. Geological Soc London, pp. 47-59.

Eldholm, O., Tsikalas, F., Faleide, J.I., 2002. Continental margin off Norway $62-75^{\circ} \mathrm{N}$ :

Palaeogene tectono-magmatic segmentation and sedimentation. Special Publication Society of London 197, 39-68.

Fernandez, M., Ayala, C., Torne, M., Verges, J., Gomez, M., Karpuz, R., 2005. Lithospheric structure of the Mid-Norwegian Margin: comparison between the More and Voring margins. Geological Soc London, pp. 1005-1012.

Fichler, C., Odinsen, T., Rueslåtten, H., Olesen, O., Vindstad, J.E., Wienecke, S., 2011. Crustal inhomogeneities in the Northern North Sea from potential field modeling: Inherited structure and serpentinites? Tectonophysics 510, 172-185.

Frasetto, A., Thybo, H., subm. Lithospheric Structure of Southern Norway and Sweden from P-Receiver Functions.

Gabrielsen, R.H., Odinsen, T., Grunnaleite, I., 1999. Structuring of the Northern Viking Graben and the Møre Basin; the influence of basement structural grain, and the particular role of the Møre-Trøndelag Fault Complex. Marine and Petroleum Geology 16, 443-465. 
Gernigon, L., Lucazeau, F., Brigaud, F., Ringenbach, J.C., Planke, S., Le Gall, B., 2006. A moderate melting model for the Vøring margin (Norway) based on structural observations and a thermo-kinematical modelling: Implication for the meaning of the lower crustal bodies. Tectonophysics 412, 255-278.

Gernigon, L., Ringenbach, J.C., Planke, S., Le Gall, B., 2004. Deep structures and breakup along volcanic rifted margins: insights from integrated studies along the outer Vøring Basin (Norway). Marine and Petroleum Geology 21, 363-372.

Gomez, M., Verges, J., Fernandez, M., Torne, M., Ayala, C., Wheeler, W., Karpuz, R., 2004. Extensional geometry of the Mid Norwegian Margin before Early Tertiary continental breakup. Marine and Petroleum Geology 21, 177-194.

Götze, H.-J., Lahmeyer, B., 1988. Application of three-dimensional interactive modeling in gravity and magnetics. Geophysics 53, 1096-1108.

Hacker, B.R., Andersen, T.B., Johnston, S., Kylander-Clark, A.R.C., Peterman, E.M., Walsh, E.O., Young, D., 2010. High-temperature deformation during continental-margin subduction \& exhumation: The ultrahigh-pressure Western Gneiss Region of Norway. Tectonophysics 480, 149-171.

Holbrook, W.S., Mooney, W.D., Christensen, N.I., 1992. The seismic velocity structure of the deep continental crust. Continental lower crust 1, 43.

Jongepier, K., Rui, J.C., Grue, K., 1996. Triassic to Early Cretaceous stratigraphic and structural development of the northeastern Møre Basin margin, off Mid-Norway. Norsk Geologisk Tidsskrift 76, 199-214.

Korenaga, J., 2011. Velocity-depth ambiguity and the seismic structure of large igneous provinces: a case study from the Ontong Java Plateau. Geophysical Journal International. Lundin, E., Doré, A.G., 2002. Mid-Cenozoic post-breakup deformation in the 'passive'margins bordering the Norwegian-Greenland Sea. Marine and Petroleum Geology 19, 79-93.

Lundin, E.R., Doré, A.G., 1997. A tectonic model for the Norwegian passive margin with implications for the NE Atlantic; Early Cretaceous to break-up. Journal of the Geological Society $154,545-550$.

Lundin, E.R., Dorè, A.G., 2011. Hyperextension, serpentinization, and weakening: A new paradigm for rifted margin compressional deformation. Geology 39, 347-350.

Maupin, V., Agostini, A., Artemieva, I., Balling, N., Beekman, F., Ebbing, J., England, R.W., Frassetto, A., Gradmann, S., Jacobsen, B.H., Köhler, A., Kvarven, T., Medhus, A.B., Mjelde, R., Ritter, J., Sokoutis, D., Stratford, W., Thybo, H., Wawerzinek, B., Weidle, C., 2013. The deep structure of the Scandes and its relation to tectonic history and present-day topography. Tectonophysics.

Mjelde, R., Digranes, P., Shimamura, H., Shiobara, H., Kodaira, S., Brekke, H., Egebjerg, T., Sørenes, N., Thorbjørnsen, S., 1998. Crustal structure of the northern part of the Vøring Basin, mid-Norway margin, from wide-angle seismic and gravity data. Tectonophysics 293, 175-205. Mjelde, R., Digranes, P., Van Schaack, M., Shimamura, H., Shiobara, H., Kodaira, S., Naess, O., Sørenes, N., Vågnes, E., 2001. Crustal structure of the outer Vøring Plateau, offshore Norway, from ocean bottom seismic and gravity data. Journal of Geophysical Research-Solid Earth 106.

Mjelde, R., Faleide, J.I., Breivik, A.J., Raum, T., 2009a. Lower crustal composition and crustal lineaments on the Vøring Margin, NE Atlantic: A review. Tectonophysics 472, 183193.

Mjelde, R., Goncharov, A., Müller, R.D., 2012. The Moho: Boundary above upper mantle peridotites or lower crustal eclogites? A global review and new interpretations for passive margins. Tectonophysics. 
Mjelde, R., Kodaira, S., Shimamura, H., Kanazawa, T., Shiobara, H., Berg, E.W., Riise, O., 1997. Crustal structure of the central part of the Vøring Basin, mid-Norway margin, from ocean bottom seismographs. Tectonophysics 277, 235-257.

Mjelde, R., Raum, T., Kandilarov, A., Murai, Y., Takanami, T., 2009b. Crustal structure and evolution of the outer Møre Margin, NE Atlantic. Tectonophysics 468, 224-243.

Mjelde, R., Raum, T., Myhren, B., Shimamura, H., Murai, Y., Takanami, T., Karpuz, R., Næss, U., 2005. Continent-ocean transition on the Vøring Plateau, NE Atlantic, derived from densely sampled ocean bottom seismometer data. Journal of Geophysical Research-Solid Earth 110, B05101.

Mjelde, R., Shimamura, H., Kanazawa, T., Kodaira, S., Raum, T., Shiobara, H., 2003. Crustal lineaments, distribution of lower crustal intrusives and structural evolution of the Vøring Margin, NE Atlantic; new insight from wide-angle seismic models. Tectonophysics 369, 199218.

Mørk, M.B.E., Johnsen, S.O., 2005. Jurassic sandstone provenance and basement erosion in the Møre margin-Froan Basin area. Norges geologiske undersøkelse Bulletin 443, 5-18. Olafsson, I., Sundvor, E., Eldholm, O., Grue, K., 1992. Møre Margin: Crustal structure from analysis of expanded spread profiles. Marine Geophysical Researches 14, 137-162. Olesen, O., Brönner, M., Ebbing, J., Gellein, J., Gernigon, L., Koziel, J., Lauritsen, T., Myklebust, R., Pascal, C., Sand, M., 2010. New aeromagnetic and gravity compilations from Norway and adjacent areas- methods and applications. Petroleum Geology: From mature basins to new frontiers. Proceedings of the $7^{\text {th }}$ Petroleum Geology Conference Conference Series 7, 559-586.

Ottesen, D., Dowdeswell, J.A., Rise, L., 2005. Submarine landforms and the reconstruction of fast-flowing ice streams within a large Quaternary ice sheet: The 2500-km-long NorwegianSvalbard margin (57-80 N). Geological Society of America Bulletin 117, 1033-1050. Pérez-Gussinyé, M., Reston, T.J., 2001. Rheological evolution during extension at nonvolcanic rifted margins- Onset of serpentinization and development of detachments leading to continental breakup. Journal of geophysical research 106, 3961-3975.

Peron-Pinvidic, G., Gernigon, L., Gaina, C., Ball, P., 2012. Insights from the Jan Mayen system in the Norwegian-Greenland Sea-II. Architecture of a microcontinent. Geophysical Journal International.

Planke, S., Rasmussen, T., Rey, S.S., Myklebust, R., 2005. Seismic characteristics and distribution of volcanic intrusions and hydrothermal vent complexes in the Vøring and Møre basins. Geological Society of London, pp. 833-844.

Prestvik, T., Torske, T., Sundvoll, B., Karlsson, H., 1999. Petrology of early Tertiary nephelinites off mid-Norway. Additional evidence for an enriched endmember of the ancestral Iceland plume. Lithos 46, 317-330.

Raum, T., 2000. Crustal structure and evolution of the Faeroe, Møre and Vøring margins from wide-angle seismic and gravity data. University of Bergen.

Raum, T., Mjelde, R., Digranes, P., Shimamura, H., Shiobara, H., Kodaira, S., Haatvedt, G., Sørenes, N., Thorbjørnsen, T., 2002. Crustal structure of the southern part of the Vøring Basin, mid-Norway margin, from wide-angle seismic and gravity data. Tectonophysics 355, 99-126.

Raum, T., Mjelde, R., Shimamura, H., Murai, Y., Bråstein, E., Karpuz, R.M., Kravik, K., Kolstø, H.J., 2006. Crustal structure and evolution of the southern Vøring Basin and Vøring Transform Margin, NE Atlantic. Tectonophysics 415, 167-202.

Redfield, T., Osmundsen, P., 2013. The long-term topographic response of a continent adjacent to a hyperextended margin: A case study from Scandinavia. Geological Society of America Bulletin 125, 184-200.

Ren, S., Skogseid, J., Eldholm, O., 1998. Late Cretaceous-Paleocene extension on the Vøring volcanic margin. Marine Geophysical Researches 20, 343-369. 
Reston, T.J., Krawczyk, C.M., Klaeschen, D., 1996. The S reflector west of Galicia (Spain): Evidence from prestack depth migration for detachment faulting during continental breakup. Journal of geophysical research 101, 8075-8091.

Reynisson, R.F., 2010. Deep structure and sub-basalt exploration of the mid-Norwegian margin with emphasis on the Møre margin. PhD Thesis, NTNU, NTNU, Trondheim.

Reynisson, R.F., Ebbing, J., Lundin, E., Osmundsen, P.T., 2010. Properties and distribution of lower crustal bodies on the mid-Norwegian margin. Petroleum Geology Conference series v7, 843-854.

Reynisson, R.F., Ebbing, J., Skilbrei, J.R., 2009. The use of potential field data in revealing the basement structure in sub-basaltic settings: an example from the Møre margin, offshore Norway. Geophysical Prospecting 57, 753-771.

Robinson, P., Terry, M.P., Carswell, D.A., van Roermund, H., Krogh, T.E., Root, D., Tucker, R.D., Solli, A., 2003. Tectono-stratigraphic setting, structure, and petrology of HP and UHP metamorphic rocks and garnet peridotites in the Western Gneiss Region. Geological Survey of Norway, Report, 107-113.

Schmidt, S., Plonka, C., Götze, H.J., Lahmeyer, B., 2011. Hybrid modelling of gravity, gravity gradients and magnetic fields. Geophysical prospecting 59, 1046-1051.

Stratford, W., Thybo, H., 2011. Seismic structure and composition of the crust beneath the southern Scandes, Norway. Tectonophysics.

Stratford, W., Thybo, H., Faleide, J.I., Olesen, O., Tryggvason, A., 2009. New Moho Map for onshore southern Norway. Geophysical Journal International 178, 1755-1765.

Svenningsen, L., Balling, N., Jacobsen, B.H., Kind, R., Wylegalla, K., Schweitzer, J., 2007. Crustal root beneath the highlands of southern Norway resolved by teleseismic receiver functions. Geophysical Journal International 170, 1129-1138.

Torske, T., Prestvik, T., 1991. Mesozoic detachment faulting between Greenland and Norway: inferences from Jan Mayen fracture zone system and associated alkalic volcanic rocks. Geology 19, 481-484.

Weidle, C., Maupin, V., Ritter, J., Kværna, T., Schweitzer, J., Balling, N., Thybo, H., Faleide, J., Wenzel, F., 2010. MAGNUS-a seismological broadband experiment to resolve crustal and upper mantle structure beneath the southern Scandes mountains in Norway.

Seismological Research Letters 81, 76-84.

Wessel, P., Smith, W.H.F., 1998. New, improved version of Generic Mapping Tools released. EOS transactions 79, 579-579.

White, R.S., Smith, L.K., Roberts, A.W., Christie, P.A.F., Kusznir, N.J., Roberts, A.M., Healy, D., Spitzer, R., Chappell, A., Eccles, J.D., 2008. Lower-crustal intrusion on the North Atlantic continental margin. Nature 452, 460-464.

White, R.S., Spence, G.D., Fowler, S.R., McKenzie, D.P., Westbrook, G.K., Bowen, A.N., 1987. Magmatism at rifted continental margins. Nature 330, 439-444.

Wilson, J.T., 1968. Static or mobile earth: the current scientific revolution. Proceedings of the American Philosophical Society 112, 309-320.

Zelt, C.A., Forsyth, D.A., 1994. Modeling wide-angle seismic data for crustal structure:

Southeastern Grenville Province. Journal of geophysical research 99, 11687.

Zelt, C.A., Smith, R.B., 1992. Seismic traveltime inversion for 2-D crustal velocity structure. Geophysical Journal International 108, 16-34.

\section{Tables}


Table 1: The observed phases on seismograms along Profile 1, including codes, number of data points, RMS residuals and $x^{2}$-misfit for each phase.

\begin{tabular}{|c|c|c|c|c|}
\hline Arrival & Code & $\begin{array}{l}\text { No of data } \\
\text { points }\end{array}$ & $\begin{array}{l}\text { RMS } \\
\text { residual }\end{array}$ & $x^{2}$ \\
\hline Refraction from Cenozoic sediments & Ps1 & 945 & 0.064 & 1.128 \\
\hline Refraction from Cretaceous sediments & $\mathrm{Ps}_{2}$ & 1362 & 0.070 & 0.774 \\
\hline Head wave from crystalline basement & $\mathrm{Pg}_{\text {Head }}$ & 911 & 0.116 & 1.340 \\
\hline Refraction from crystalline basement & Pg & 5148 & 0.124 & 1.330 \\
\hline Refraction from upper mantle & Pn & 2351 & 0.212 & 1.383 \\
\hline Reflections from Top Cenomanian & PsP & 542 & 0.115 & 0.834 \\
\hline Reflection from Base Cretaceous sediments & $\mathrm{Ps}_{2} \mathrm{P}$ & 508 & 0.142 & 0.895 \\
\hline Reflection from top crystalline basement & $\mathrm{PgP}$ & 586 & 0.148 & 0.980 \\
\hline Reflections from middle crust & $\mathrm{Pg}_{2} \mathrm{P}$ & 1685 & 0.193 & 1.654 \\
\hline Refraction from top LCB & $\mathrm{P}_{\mathrm{LCB}} \mathrm{P}$ & 336 & 0.068 & 0.209 \\
\hline Reflection from Moho & PmP & 4954 & 0.194 & 1.680 \\
\hline
\end{tabular}

Table 2: The observed phases on seismograms along Profile 2, including codes, number of data points, RMS residuals and $x^{2}$-misfit for each phase.

\begin{tabular}{|c|c|c|c|c|}
\hline Arrival & Code & $\begin{array}{l}\text { No of data } \\
\text { points }\end{array}$ & $\begin{array}{l}\text { RMS } \\
\text { residual }\end{array}$ & $x^{2}$ \\
\hline Refraction from Cenozoic sediments & Ps1 & 605 & 0.074 & 1.117 \\
\hline Refraction from Cretaceous sediments & $\mathrm{Ps}_{2}$ & 1092 & 0.088 & 1.054 \\
\hline Refraction from Pre-Cretaceous sediments & $\mathrm{Ps}_{3}$ & 278 & 0.093 & 1.004 \\
\hline Refraction from flood basalt & $\mathrm{P}_{\mathrm{FB}}$ & 394 & 0.078 & 0.958 \\
\hline Head wave from crystalline basement & $\mathrm{Pg}_{\text {Head }}$ & 198 & 0.149 & 1.548 \\
\hline Refraction from crystalline basement & $\mathrm{Pg}$ & 2461 & 0.106 & 0.908 \\
\hline Refraction from LCB underneath the margin & $\mathrm{P}_{\mathrm{LCB}}$ & 246 & 0.169 & 0.881 \\
\hline Refraction from LCB underneath the coast & $\mathrm{P}_{\mathrm{LCB} 2}$ & 1735 & 0.203 & 1.774 \\
\hline Refraction from upper mantle & Pn & 1567 & 0.169 & 0.756 \\
\hline Reflection from top crystalline basement & $\mathrm{PgP}$ & 240 & 0.115 & 0.813 \\
\hline Reflection from top LCBs / Moho & PmP & 1440 & 0.152 & 1.025 \\
\hline Floating reflector & $\mathrm{P}_{\mathrm{FL}} \mathrm{P}$ & 533 & 0.160 & 1.030 \\
\hline
\end{tabular}


Table 3: The observed phases on seismograms along Profile 3, including codes, number of data points, RMS residuals and $x^{2}$-misfit for each phase.

\begin{tabular}{|c|c|c|c|c|}
\hline Arrival & Code & $\begin{array}{l}\text { No of data } \\
\text { points }\end{array}$ & $\begin{array}{l}\text { RMS } \\
\text { residual }\end{array}$ & $x^{2}$ \\
\hline Refraction from Cenozoic sediments & Ps1 & 576 & 0.069 & 1.603 \\
\hline Refraction from Cretaceous sediments & $\mathrm{Ps}_{2}$ & 968 & 0.073 & 1.263 \\
\hline Refraction from Pre-Cretaceous sediments & $\mathrm{Ps}_{3}$ & 101 & 0.082 & 1.049 \\
\hline Refraction from crystalline basement & Pg & 6862 & 0.095 & 0.903 \\
\hline Refraction from Lover Crustal Body (LCB) & $\mathrm{P}_{\mathrm{LCB}}$ & 98 & 0.059 & 0.096 \\
\hline Refraction from upper mantle & Pn & 972 & 0.116 & 0.416 \\
\hline Reflections from Base Cretaceous & $\mathrm{Ps}_{2} \mathrm{P}$ & 159 & 0.057 & 0.513 \\
\hline Reflections from middle crust & Pg2P & 1685 & 0.142 & 1.642 \\
\hline Refraction from top LCB /Moho & $\mathrm{P}_{\mathrm{LCB}} \mathrm{P}$ & 3219 & 0.162 & 1.148 \\
\hline Reflections from floating reflectors & $\mathrm{P}_{\text {float }} \mathrm{P}$ & 899 & 0.162 & 1.153 \\
\hline
\end{tabular}




\section{Figure captions}

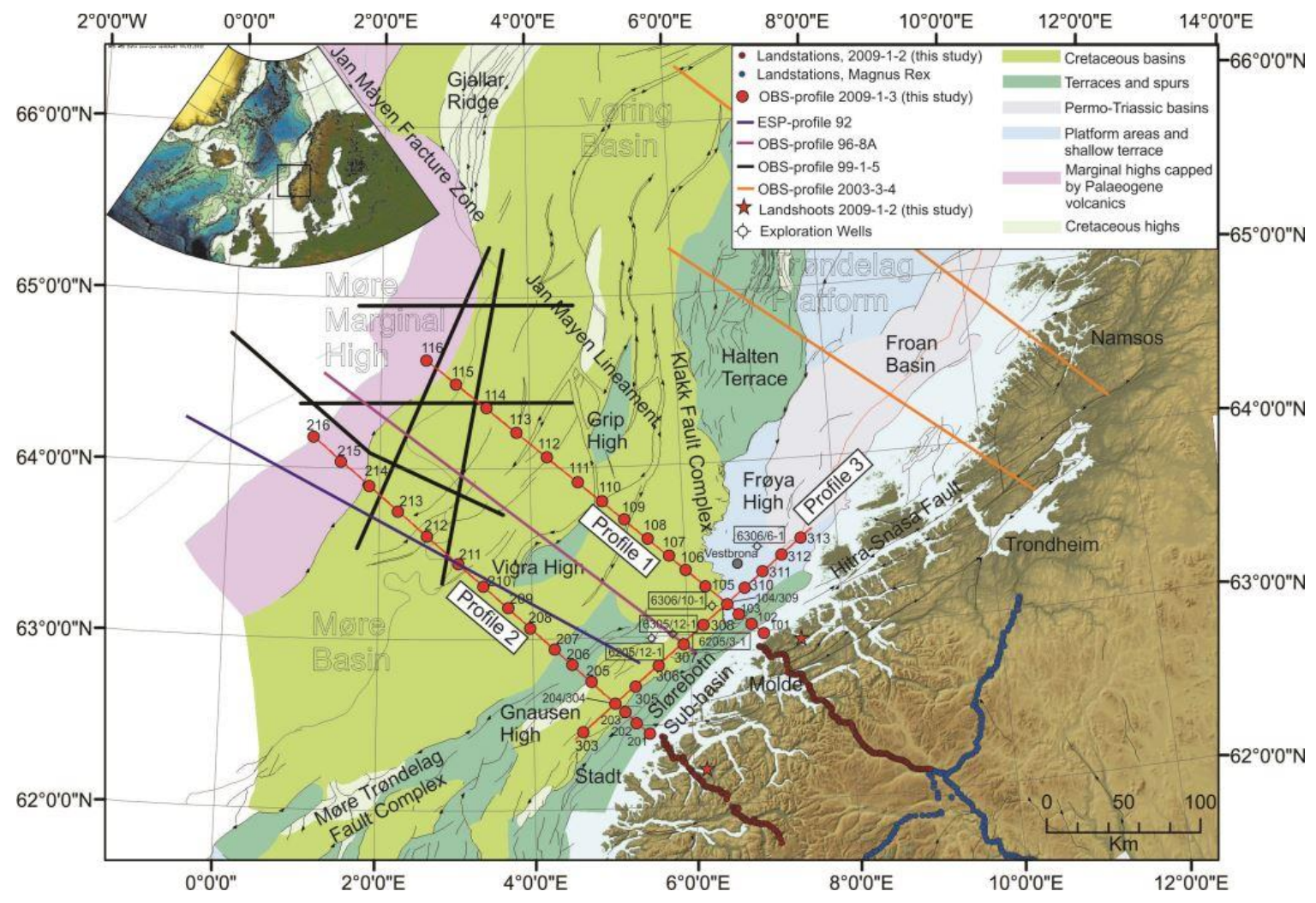

Figure 1: The Møre Basin with wide-angle seismic surveys. The profiles discussed in this paper are marked in red (airgun shots - solid line, recording instruments - dots, stars landshots). The blue line indicates the Extended Spread Profiles (ESP) (Olafsson et al., 1992). The pink line shows the parallel OBS study of Raum (2000). The black lines indicate the OBS study of the outer Møre Margin (Mjelde et al., 2009b). The orange lines show the OBS/land station study on the Trøndelag Platform (Breivik et al., 2011). The dark blue circles mark the land stations of the Magnus Rex experiment (Stratford and Thybo, 2011). The empty circles show exploration wells. Map modified from Norwegian Petroleum Directorate's web page: http://npdwms.npd.no/npdwmsmap_wgs84.asp and from Norwegian Mapping Authority’s web page: http://wms.geonorge.no/skwms1/wms.terrengmodell? 


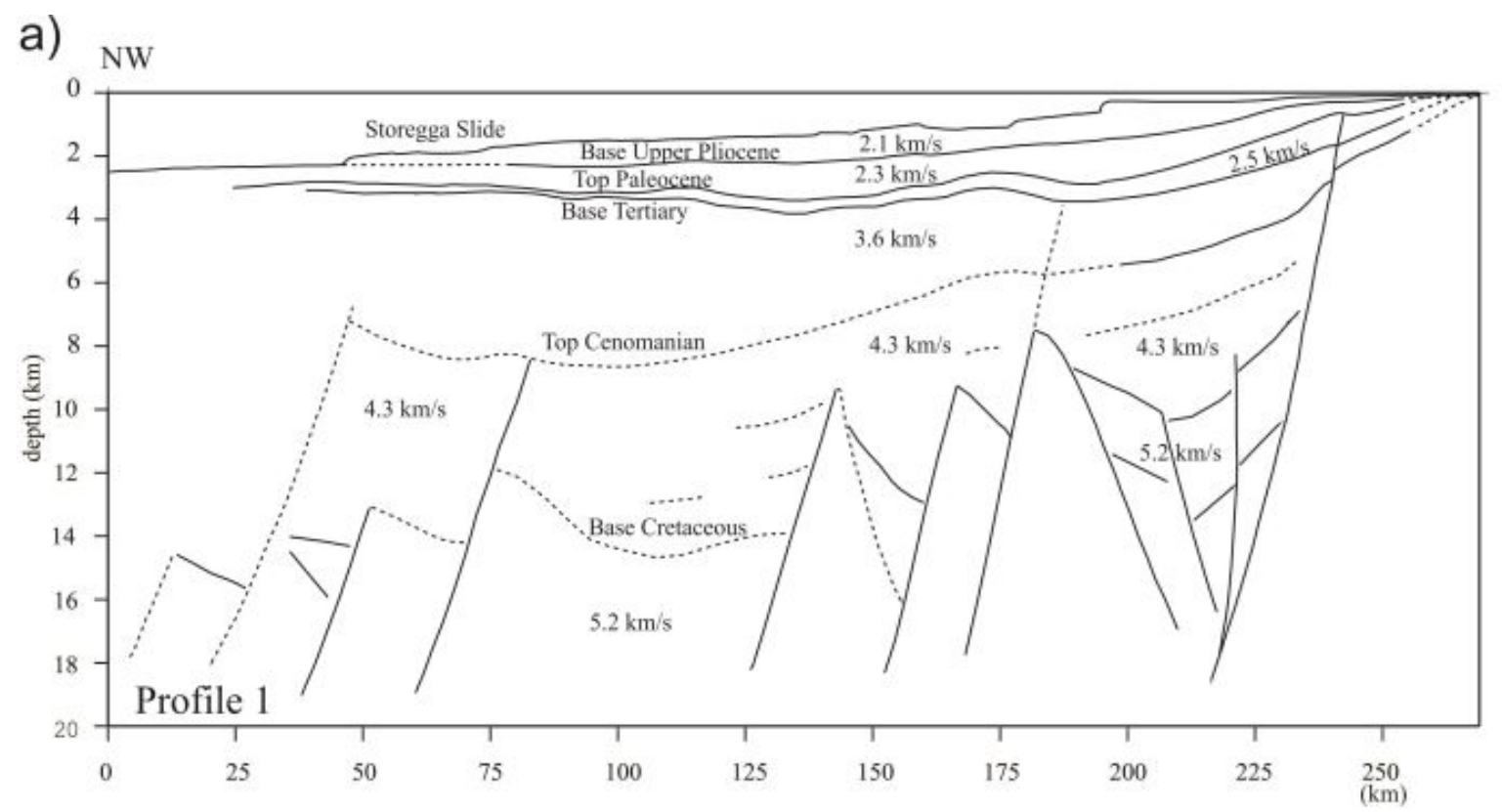

b) $\mathrm{NW}$

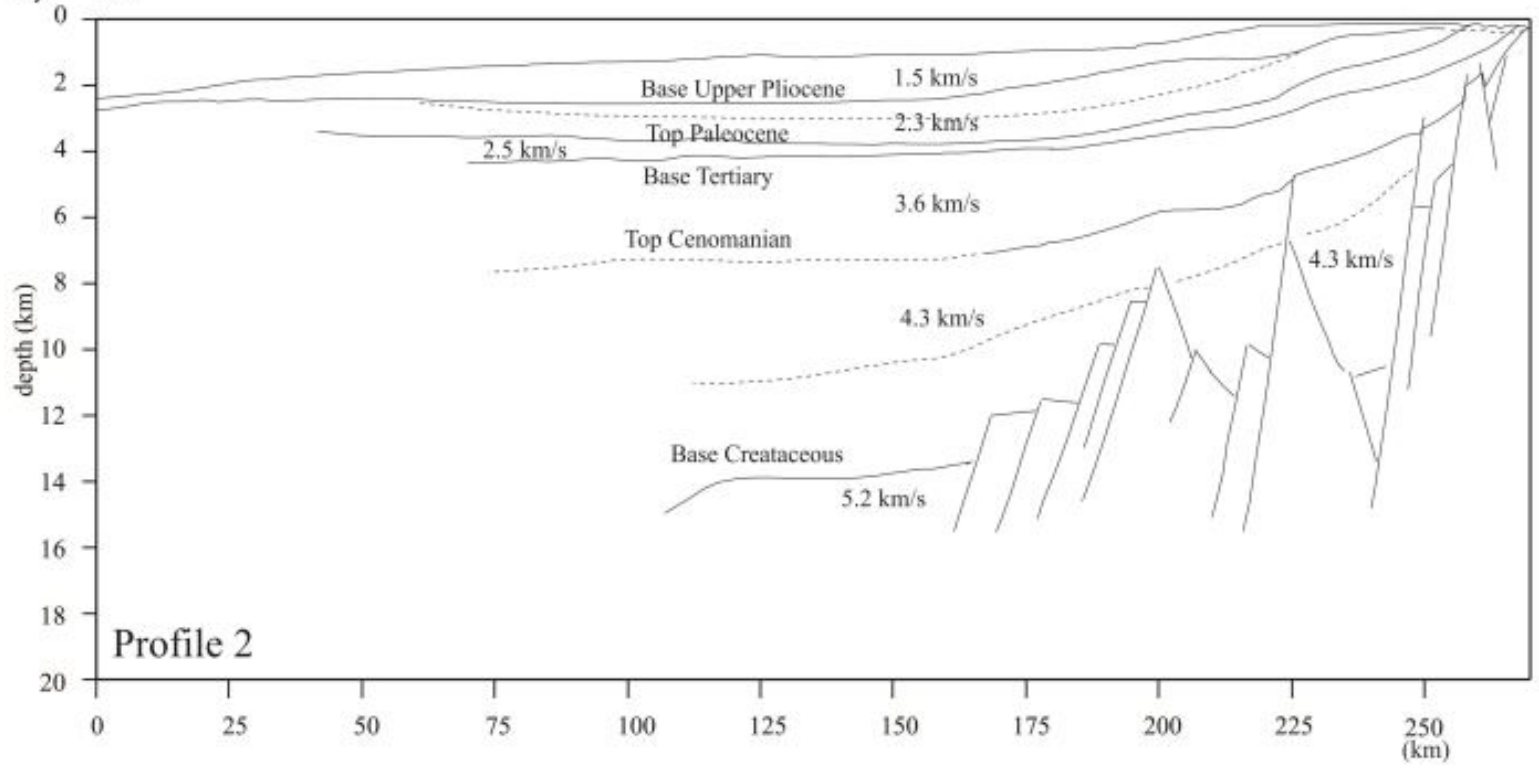

c) $\mathrm{NE}$

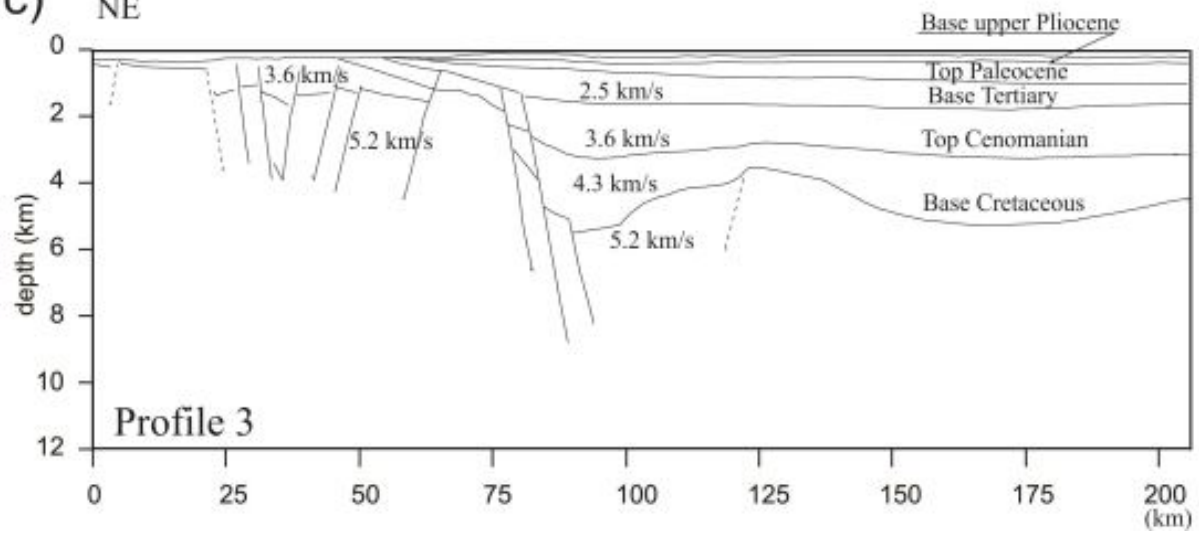


Figure 2: Starting models for Profiles 1, 2 and 3. a) Profile 1 is along the MCS line NPDSTOR-85. b) Profile 2 is based on the MCS lines GOM-95-411 and NPD-MB-92-12 and -18.

c) Profile 3 is constructed from a compilation of multiple MCS data sets: SG9113, MM95, MMI97, ST8705, ST8707, SG9308 and NPD-STOR-85.
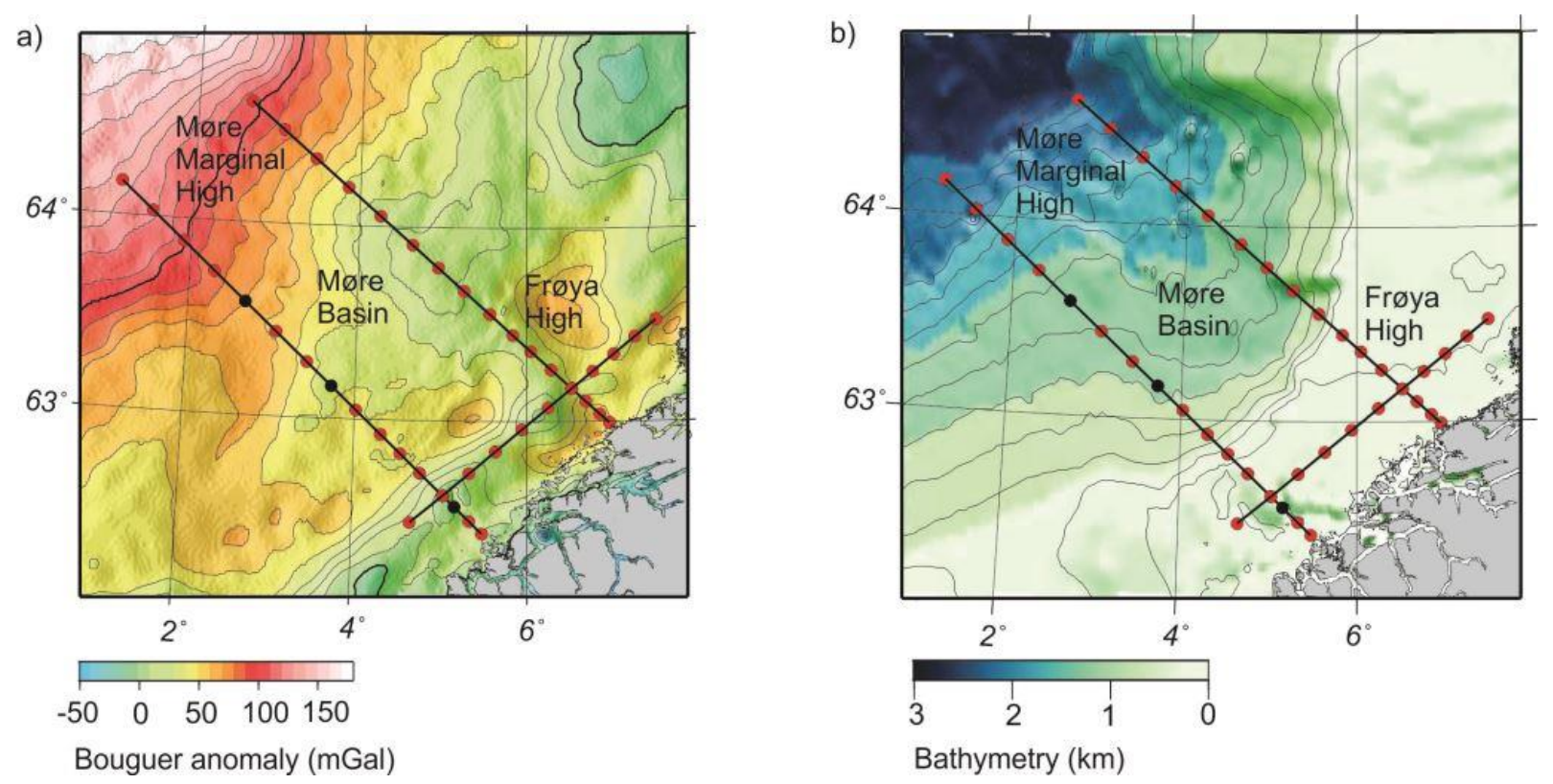

Figure 3: a) The OBS profiles superimposed on a map of Bouguer anomalies calculated from the global gravity model DTU 10 with a reduction density of $2200 \mathrm{~kg} / \mathrm{m}^{3}$. The Frøya High is a basement high with a positive gravity anomaly and magnetic high. b) The OBS profiles superimposed on a map with bathymetry based on 2-minute Gridded Global Relief Data (ETOPO2v2) from the U.S. Department of Commerce, National Oceanic and Atmospheric Administration, National Geophysical Data Center, 2006 ( http://www.ngdc.noaa.gov/mgg/fliers/06mgg01.html). Red circles: OBS instruments. Grey circles: Malfunctioning or low-quality OBS instruments. 

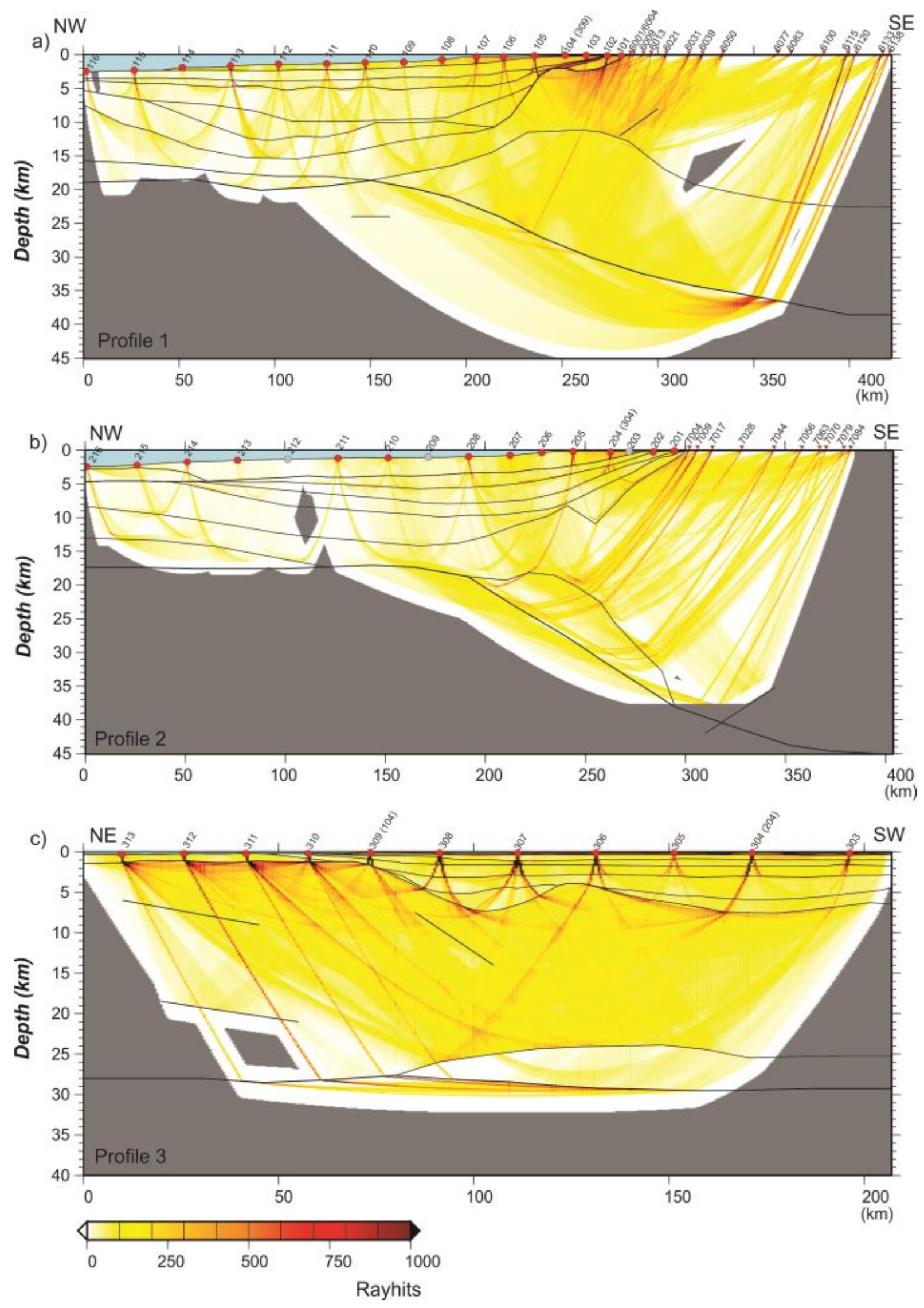
Figure 4: a) Ray coverage for Profile 1. b) Ray coverage for Profile 2. c) Ray coverage for Profile 3. Cell size is $0.5 \mathrm{~km}$ in $\mathrm{x}$-direction and $0.1 \mathrm{~km}$ in z-direction. Red circles: OBS instruments. Grey circles: Malfunctioning or low-quality OBS instruments. Red triangles: land stations.

a)

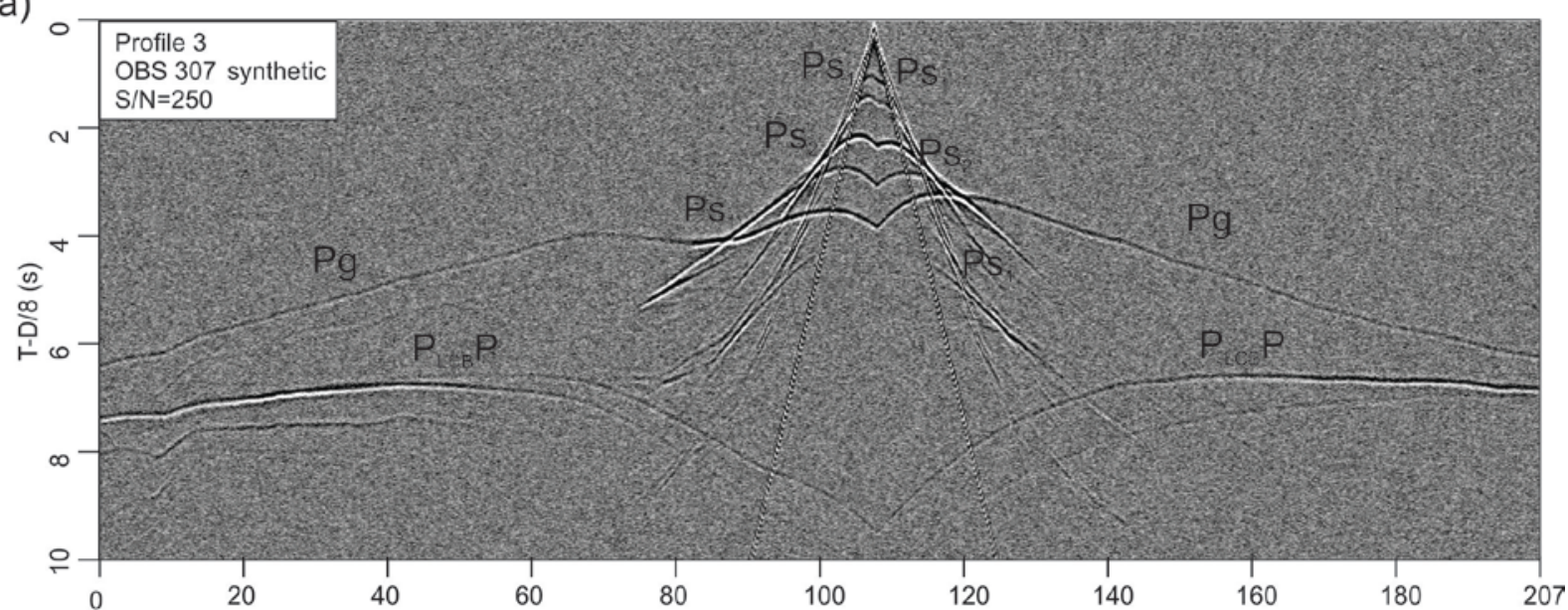

b)
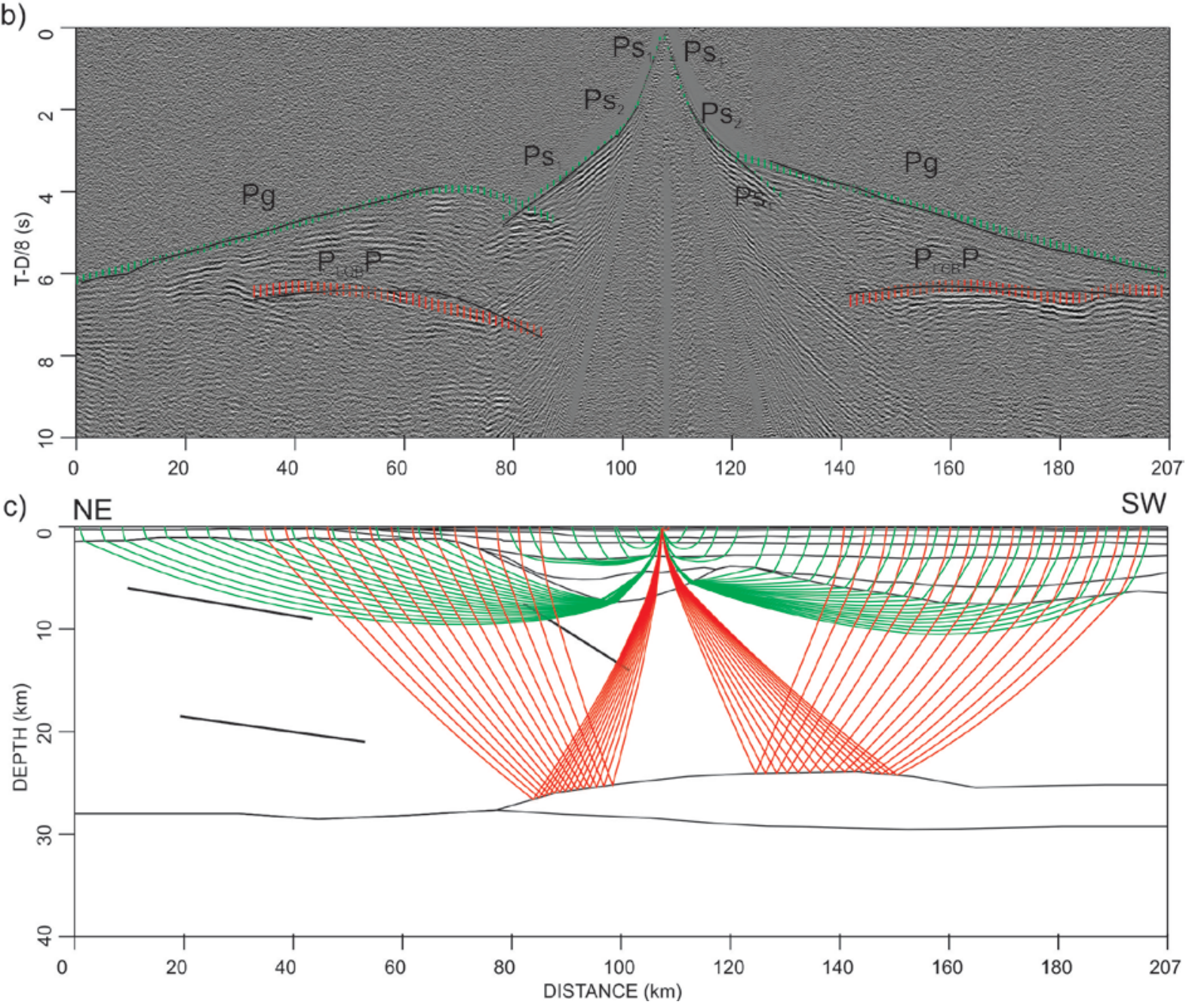
Figure 5: Profile 3, OBS 307. a) Synthetic seismic section. b) Seismic section with interpretation and modelled traveltime curves. The height of the colorbars is reflecting the assigned uncertainty for each phase. c) P- wave velocity model with calculated ray paths. Refracted waves in green colour and reflected waves in red colour. The bold black lines are floating reflectors. 

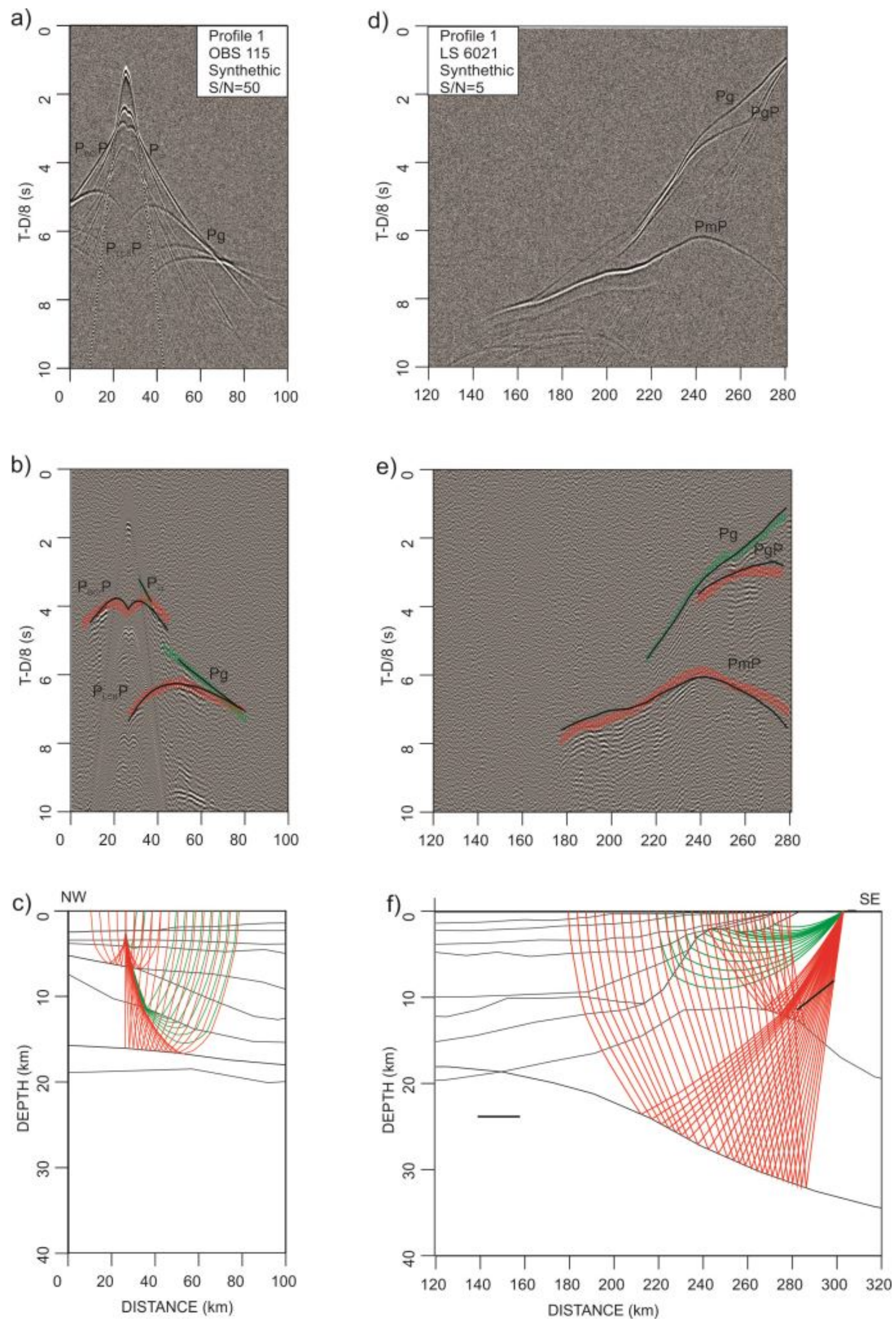
Figure 6: a) Synthetic seismic section OBS 115. b) Seismic section with interpretation and modelled traveltime curves. The height of the colorbars is reflecting the assigned uncertainty for each phase. c) P- wave velocity model with calculated ray paths. Refracted waves are in green colour and reflected waves are in red colour. d) Synthetic sseismic section land station 6021. e) Seismic section with interpretation and modelled traveltime curves. The height of the colorbars is reflecting the assigned uncertainty for each phase. f) P- wave velocity model with calculated ray paths. Refracted waves are in green colour and reflected waves are in red colour. The bold black lines are floating reflectors.

a)

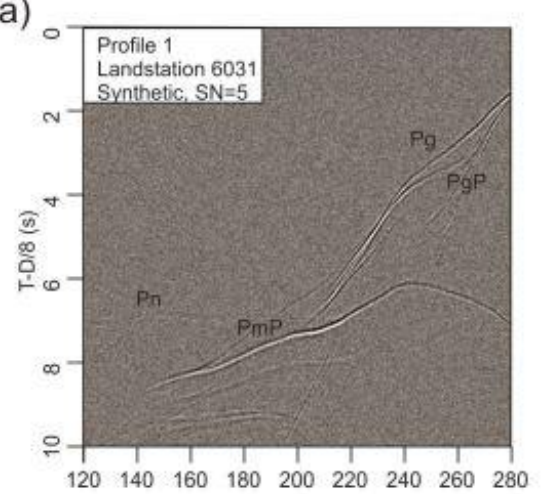

b)

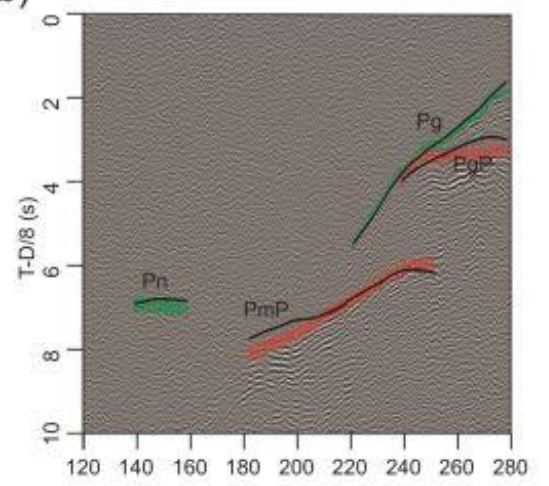

c) NW

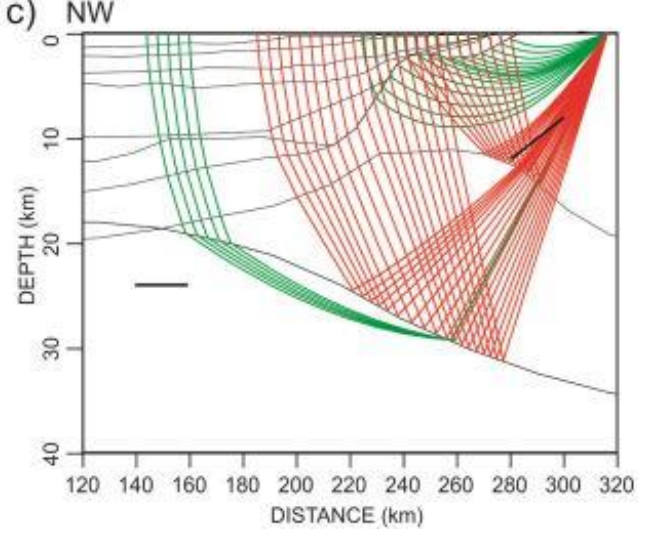

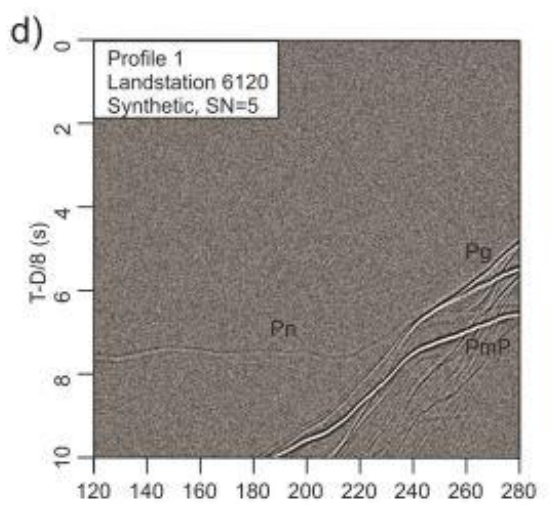

e)
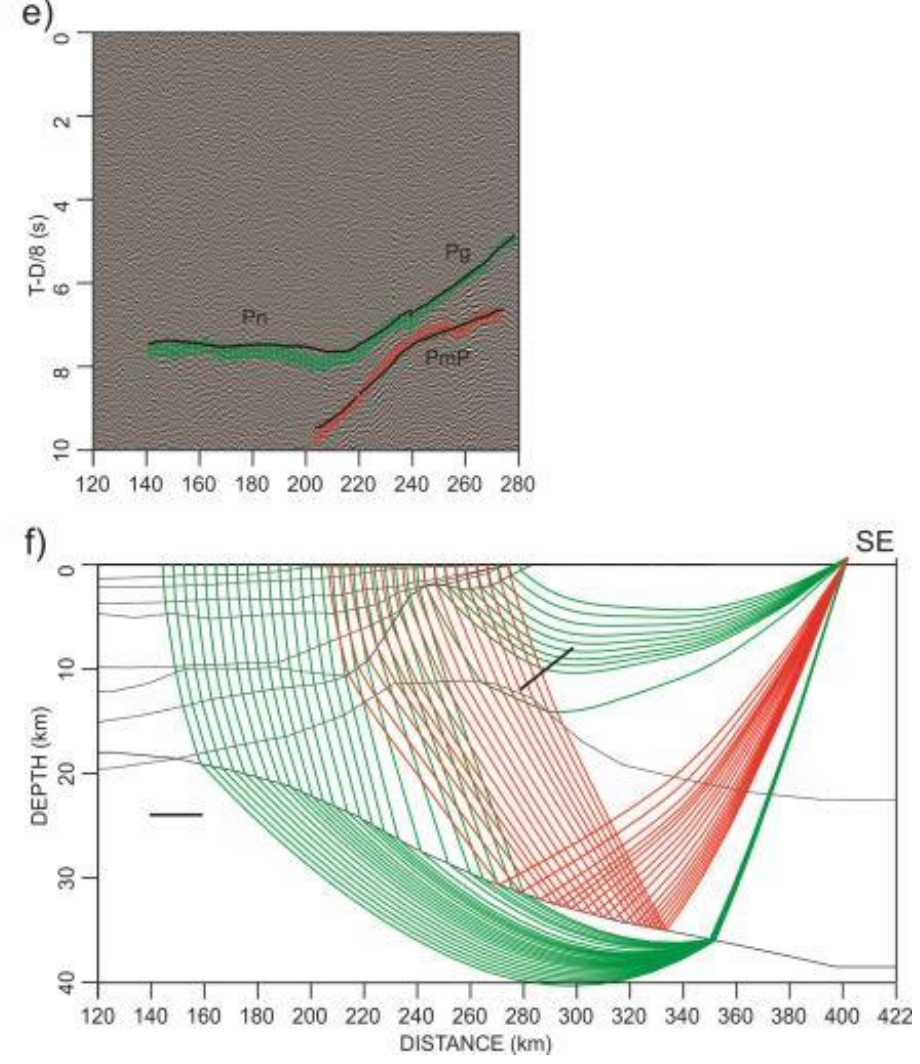
Figure 7: a) Synthetic seismic section land station 6031. b) Seismic section with interpretation and modelled traveltime curves. The height of the colorbars is reflecting the assigned uncertainty for each phase. c) P- wave velocity model with calculated ray paths. Refracted waves are in green colour and reflected waves are in red colour. The bold black lines are floating reflectors.

d) Synthetic seismic section land station 6120. e) Seismic section with interpretation and modelled traveltime curves. The height of the colorbars is reflecting the assigned uncertainty for each phase. f) P- wave velocity model with calculated ray paths. Refracted waves are in green colour and reflected waves are in red colour. The bold black lines are floating reflectors. 
a)

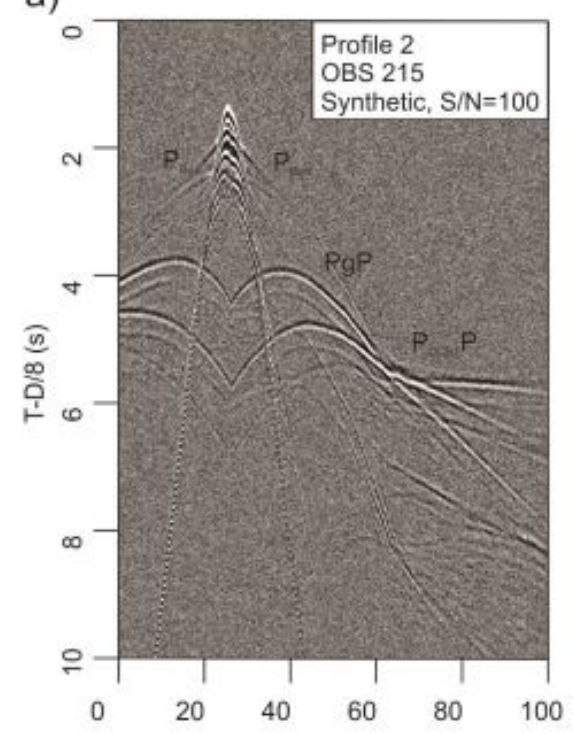

b)

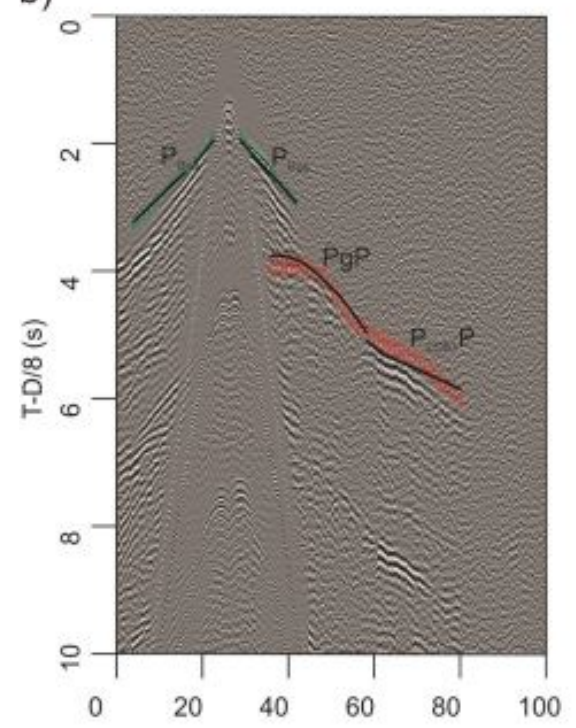

c) $\mathrm{NW}$

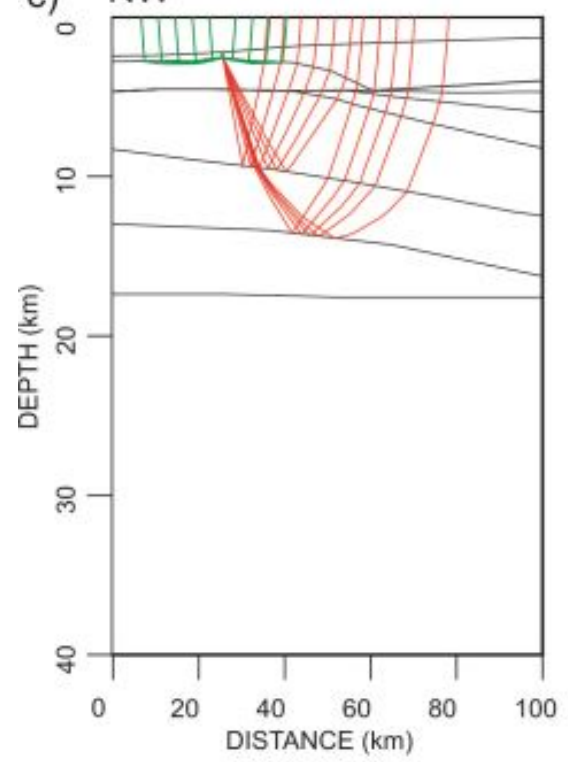

d)

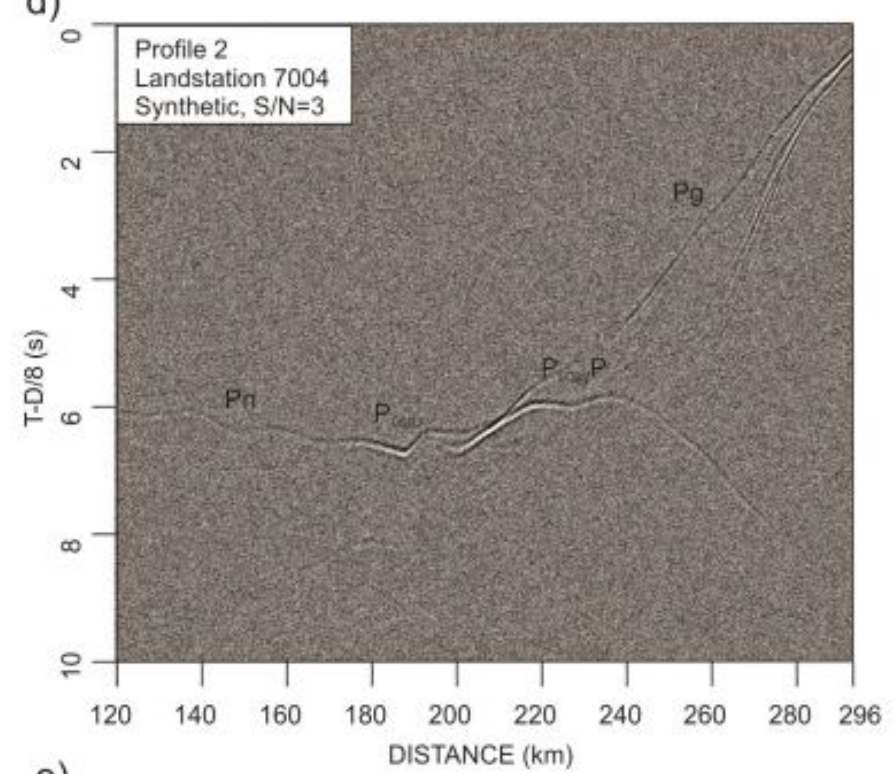

e)

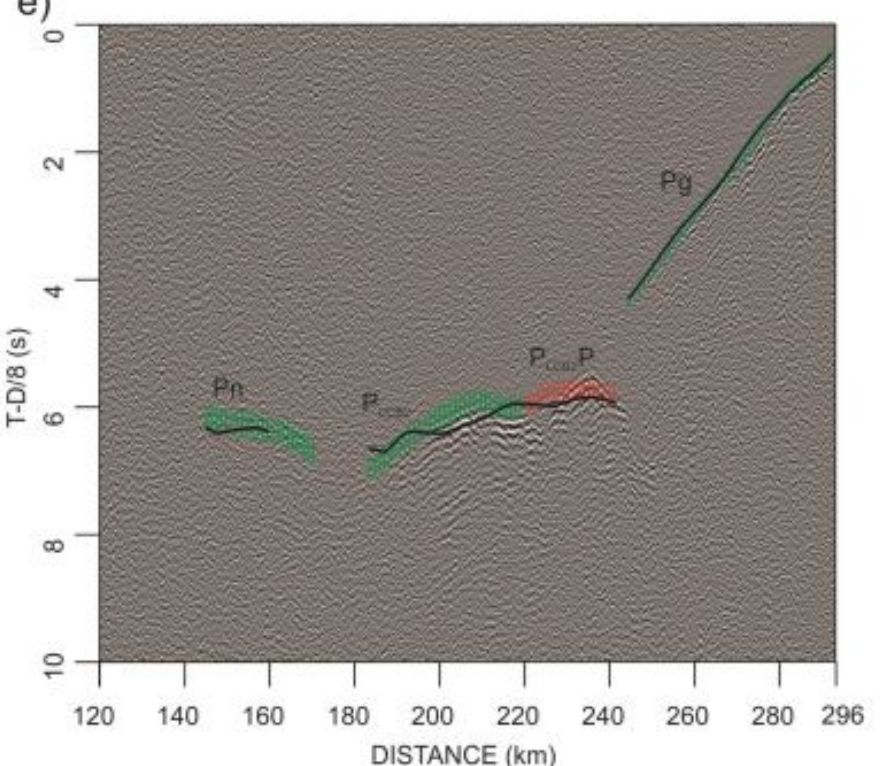

f)

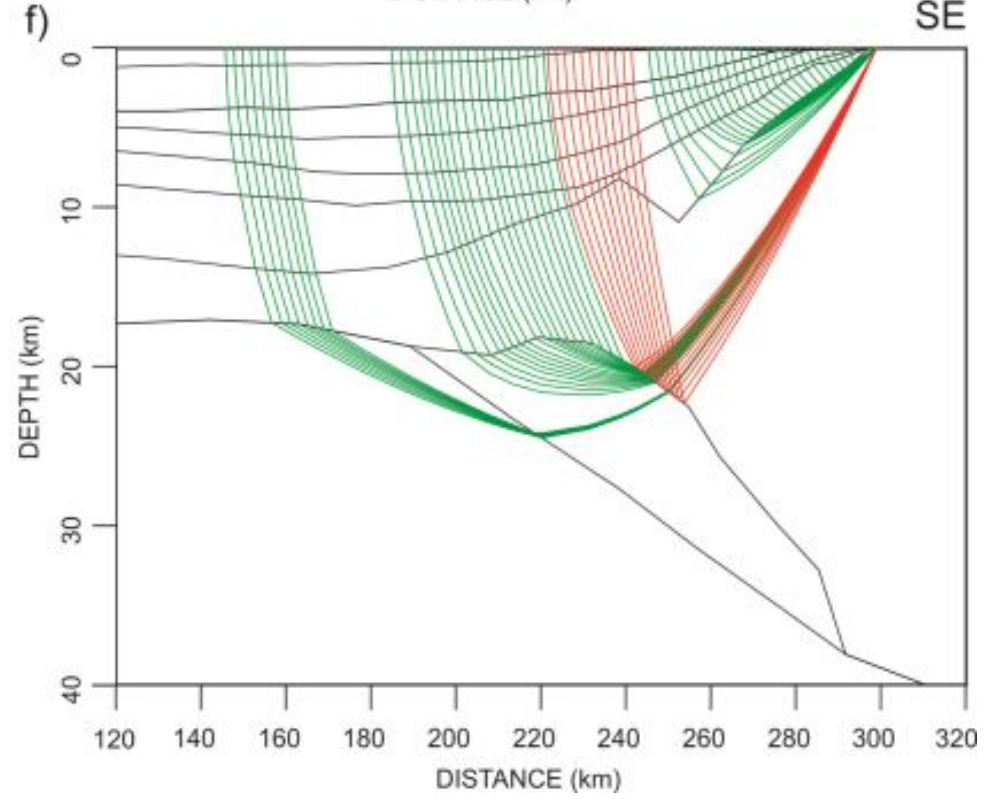


Figure 8: a) Synthetic seismic section OBS 215. b) Seismic section with interpretation and modelled traveltime curves. The height of the colorbars is reflecting the assigned uncertainty for each phase. c) P- wave velocity model with calculated ray paths. Refracted waves are in green colour and reflected waves are in red colour. d) Synthetic seismic section land station 7004. e) Seismic section with interpretation and modelled traveltime curves. The height of the colorbars is reflecting the assigned uncertainty for each phase. f) P- wave velocity model with calculated ray paths. Refracted waves are in green colour and reflected waves are in red colour.

a)

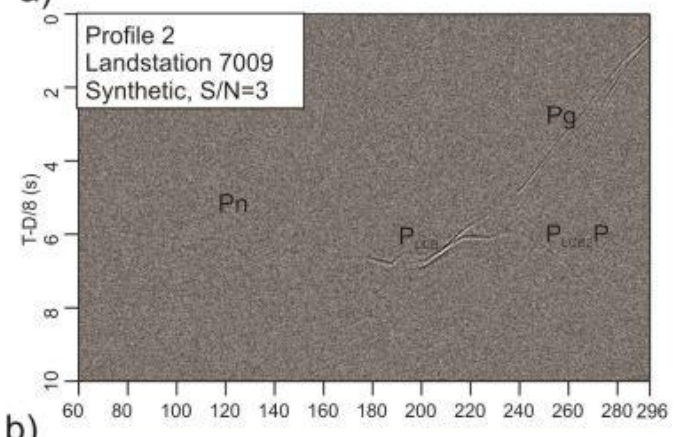

b)

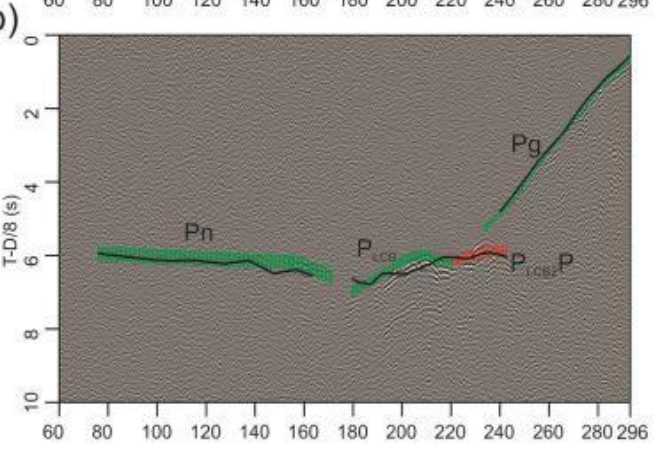

c)

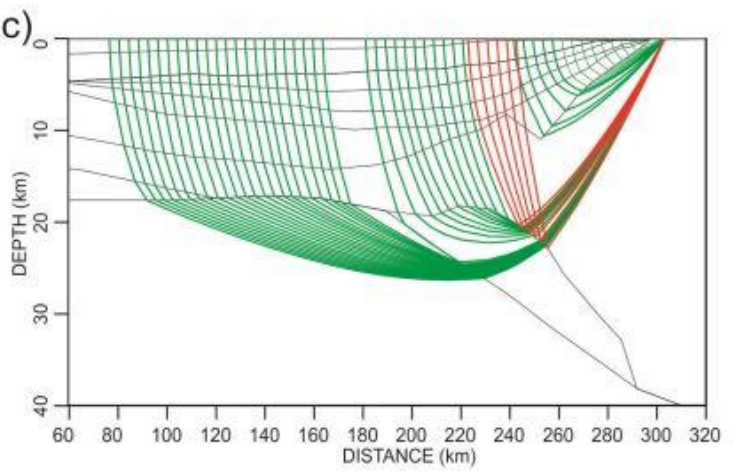

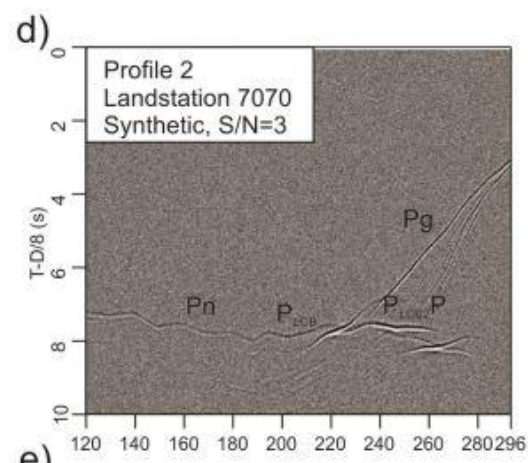

e)

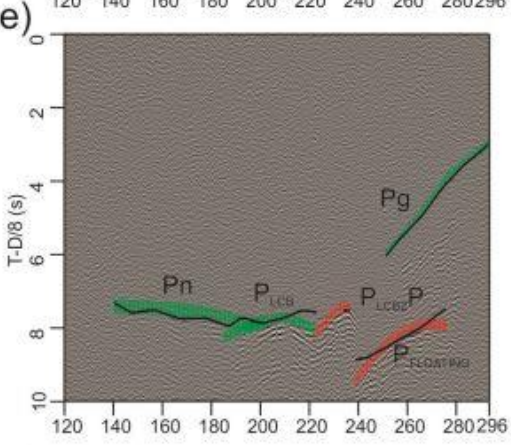

f)

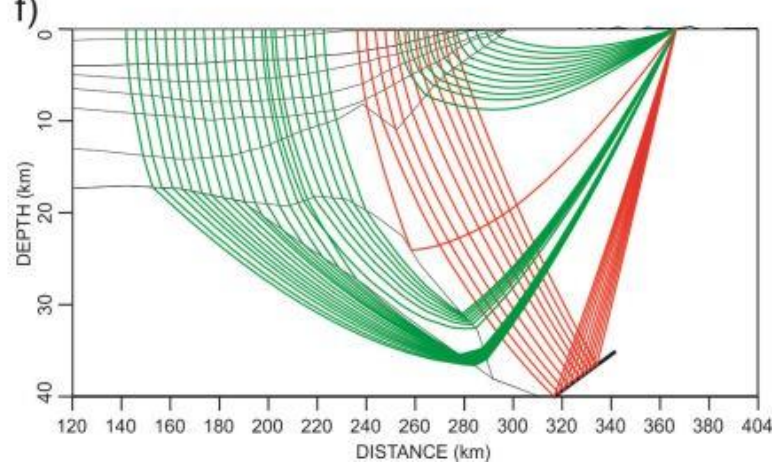

Figure 9: a) Synthetic seismic section land station 7009. b) Seismic section with interpretation and modelled traveltime curves. The height of the colorbars is reflecting the assigned uncertainty for each phase. c) P- wave velocity model with calculated ray paths. Refracted waves are in green colour and reflected waves are in red colour. d) Synthetic 
seismic section land station 7070. e) Recorded seismogram with interpretation and modelled traveltime curves. The height of the colorbars is reflecting the assigned uncertainty for each phase. f) P- wave velocity model with calculated ray paths. Refracted waves are in green colour and reflected waves are in red colour. The bold black lines are floating reflectors. 

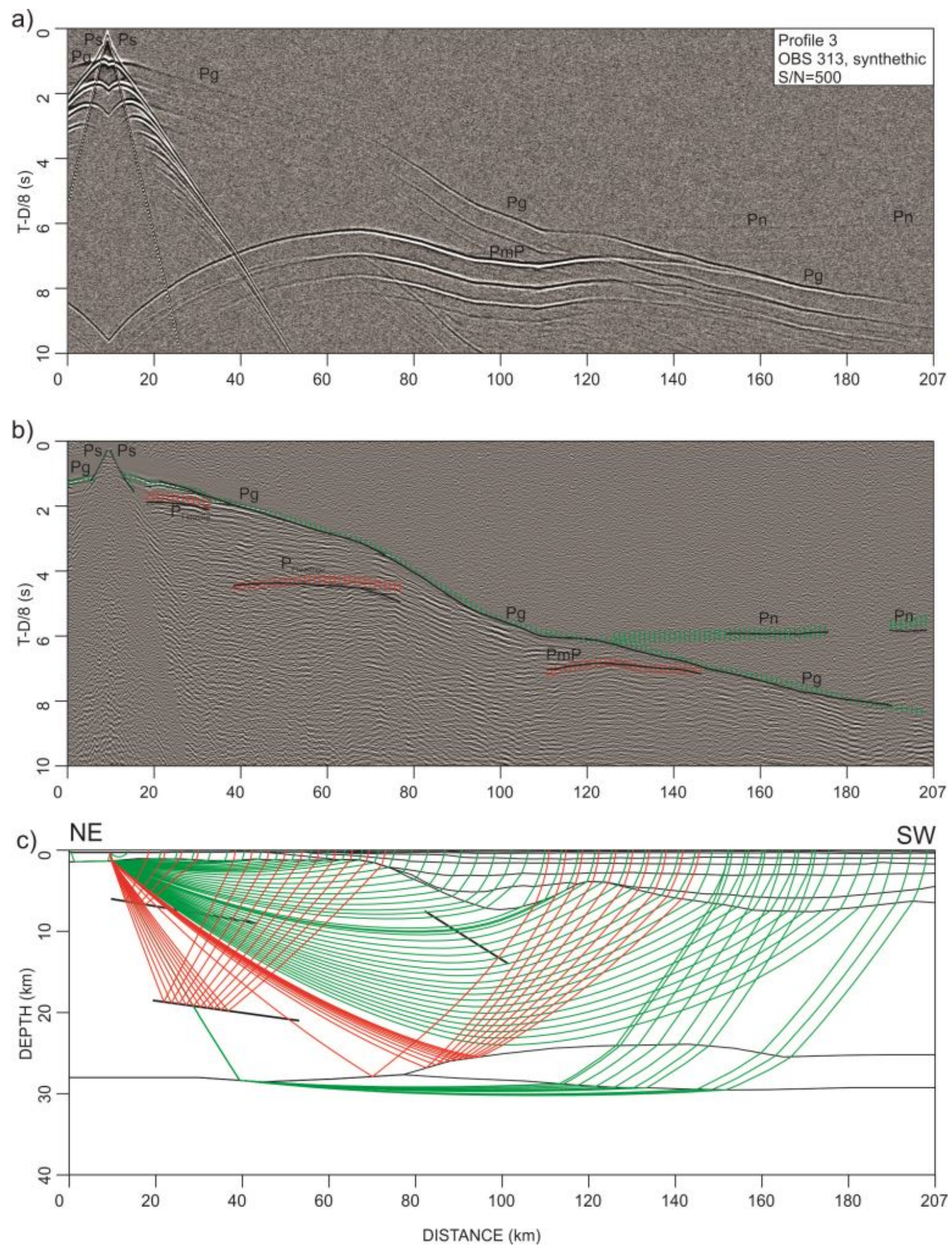

Figure 10: Profile 3, OBS 313.

a) Synthetic seismic section. b) Seismic section with interpretation and modelled traveltime curves. The height of the colorbars is reflecting the assigned uncertainty for each phase. c) P- 
wave velocity model with calculated ray paths. Refracted waves in green colour and reflected waves in red colour. The bold black lines are floating reflectors.

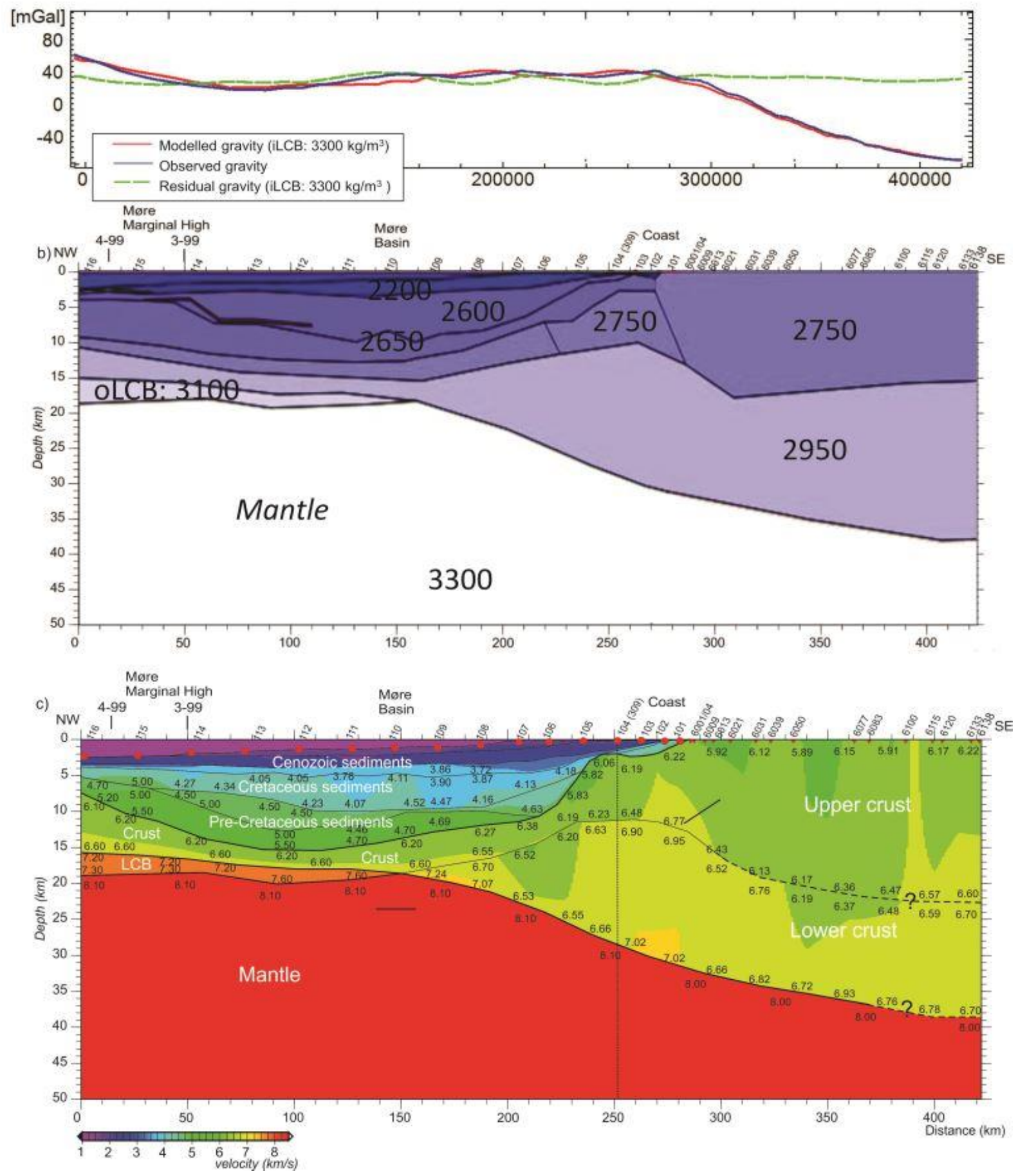

Figure 11: Profile 1. a) Observed and calculated free air gravity anomalies together with their difference (residual). b) Density model. oLCB: Outer Lower Crustal Body. c) P-wave velocity model. Red circles: OBS instruments. Red triangles: Land stations used in the modeling. Bold black lines: Floating reflectors. 


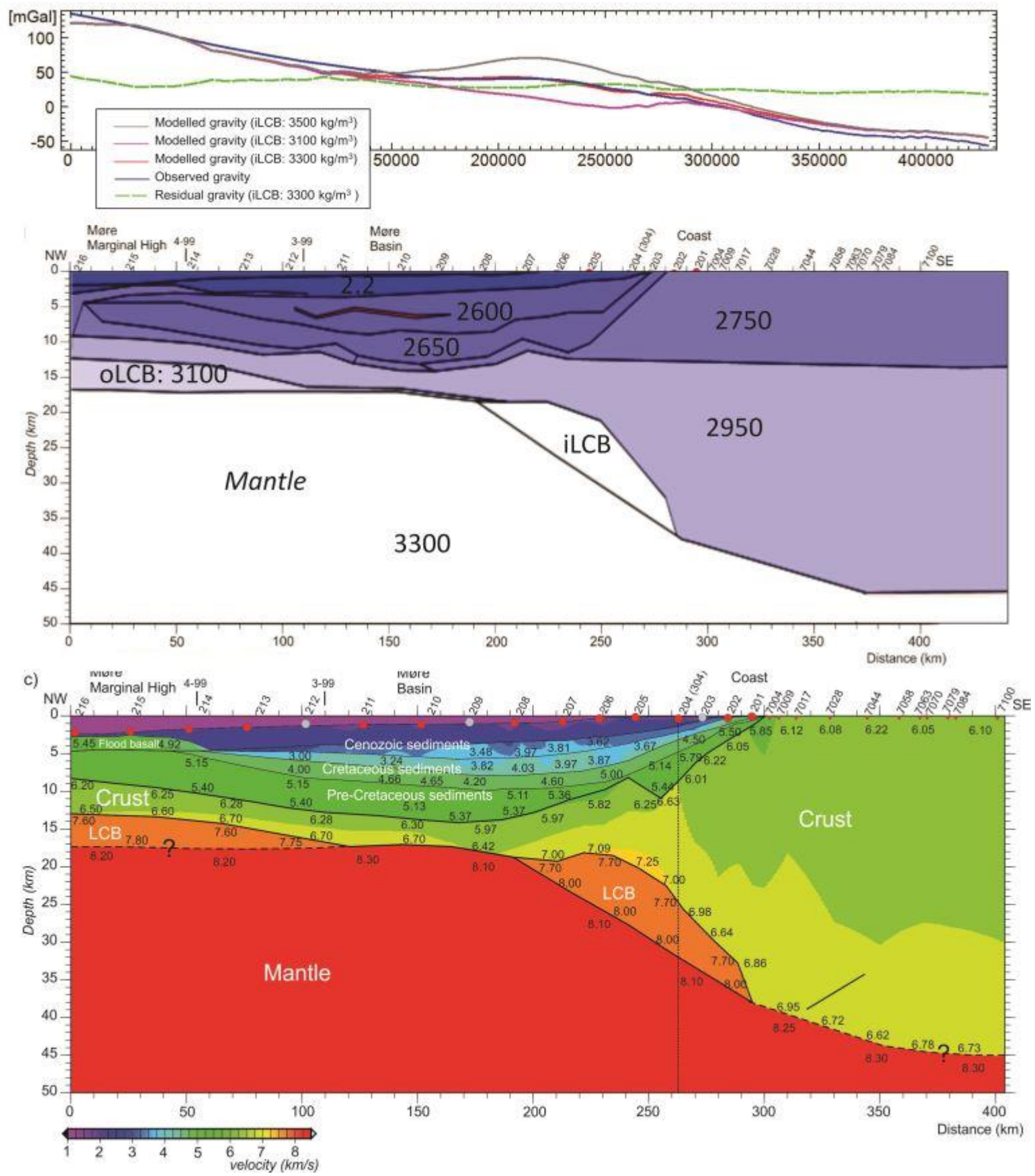

Figure 12: Profile 2. a) Gravity effect of density model for varying densities for the iLCB. The best fit between modeled and observed data is achieved for an iLCB density of 3300 $\mathrm{kg} / \mathrm{m}^{3}$. b) Density model. oLCB: Outer Lower Crustal Body. iLCB: inner Lower Crustal Body. c) P-wave velocity model. Red circles: OBS instruments. Red triangles: Land stations used in the modeling. Bold black lines: Floating reflectors. 

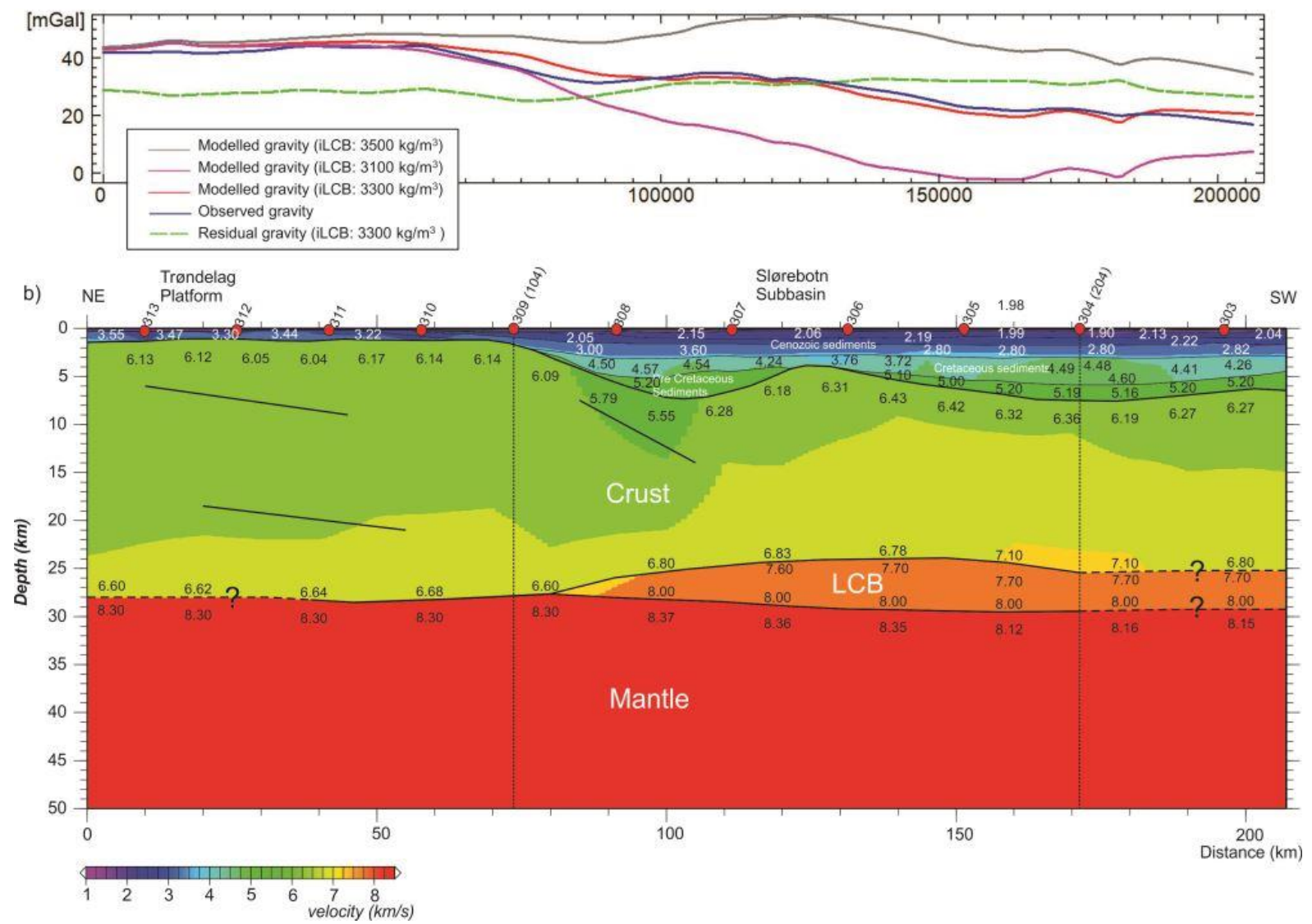

Figure 13: Profile 3. a) Gravity effect of density model for varying densities for the LCB. The best fit between modeled and observed data is achieved for a density of $3300 \mathrm{~kg} / \mathrm{m}^{3}$. The density structure is not shown as the gravity field reflects the 3D geometry of the margin (see Figure 3) and not only the 2D density structure. b) P-wave velocity model. Red circles: OBS instruments. Red triangles: Land stations used in the modeling. Bold black lines: Floating reflectors. 